\title{
Chemical Characterization of Marine Aerosols in a South Mediterranean Coastal Area Located in Bou Ismaïl, Algeria
}

\author{
Sidali Khedidji ${ }^{1,2}$, Konrad Müller ${ }^{3}$, Lyes Rabhi',4, Gerald Spindler ${ }^{3}$, Khanneh Wadinga Fomba ${ }^{3}$, \\ Dominik van Pinxteren $^{3}$, Noureddine Yassaa ${ }^{2,5,6 *}$, Hartmut Herrmann ${ }^{3 * *}$ \\ ${ }^{I}$ Departments of Chemistry, University of Akli Mohand Oulhadj, Bouira 10000, Algeria \\ ${ }^{2}$ Faculty of Chemistry, University of Sciences and Technology Houari Boumediene (USTHB), BP 32 El-Alia Bab-Ezzouar, \\ 16111 Algiers, Algeria \\ ${ }^{3}$ Atmospheric Chemistry Department (ACD), Leibniz Institute for Tropospheric Research (TROPOS), Permoserstraße 15, \\ 04318 Leipzig, Germany \\ ${ }^{4}$ Unité de Recherche en Analyses et Développement Technologiques en Environnement-Centre de Recherche Scientifique \\ et Technique en Analyses Physico-chimiques UR-ADTE-CRAPC, BP 384, Zone industrielle RP, 42004 Bou Ismail, \\ Tipaza, Algérie \\ ${ }^{5}$ Centre de Développement des Energies Renouvelables (CDER), BP 62, Route de l'Observatoire, Bouzaréah, Algiers, \\ Algeria \\ ${ }^{6}$ Commissariat aux Energies Renouvelables et à l'Efficacité Energétique, CEREFE, 12 Rue Docteur Saâdane, Algiers, \\ Algeria
}

\begin{abstract}
Daily concentrations of inorganic and organic compounds associated with $\mathrm{PM}_{10}$, i.e., atmospheric particulate matter with aerodynamic diameter of less than $10 \mu \mathrm{m}$, was determined at the south Mediterranean coastal area located in Bou Ismail, $40 \mathrm{~km}$ west of the Algiers city area in Algeria. From September 2011 to January 2012, chemical characterization of aerosol particles comprising water-soluble ions (WSI), trace metals, carbonaceous aerosols, the anhydrosugars levoglucosan and arabitol, dicarboxylic acids, and semi-volatile organic compounds (SVOC), i.e., alkanes, PAHs, and hopanes, was carried out by using a variety of analytical techniques. Overall, the concentrations of selected ionic species were similar to those reported at other Mediterranean sites, ranging from $3.62 \mu \mathrm{g} \mathrm{m}^{-3}$ to $5.20 \mu \mathrm{g} \mathrm{m}^{-3}$ for the monthly total WSI. Sulfate was the most abundant ion. The total concentrations of semi-volatile organic compounds (SVOC) recorded in Bou Ismaïl ranged from 7.06 to $58.8 \mathrm{ng} \mathrm{m}^{-3}$ for n-alkanes, from 2.44 to $35.3 \mathrm{ng} \mathrm{m}^{-3}$ for polycyclic aromatic hydrocarbons (PAHs), from 0.14 to $1 \mathrm{ng} \mathrm{m}^{-3}$ for hopanes, and from 0.67 to $13.2 \mathrm{ng} \mathrm{m}^{-3}$ for $\mathrm{n}$-alkan-2-one. In order to reconcile species concentrations and their emission sources, sampling days were grouped into two categories according to air mass origin. In the first group, the aerosol particles were mainly of a marine origin, while those of the second group originated in the dust sector. A source analysis of total contents organic compounds (PAHs, alkanes, hopanes, and alkanones) and individual inorganic compounds by spearman rank correlation illustrated that the principal sources consisted of sea salt, secondary aerosol, and biomass burning. Additionally, $\mathrm{PM}_{10}$ constituent diagnostic ratios and the carbon preference index (CPI) for $n$-alkanes indicated the importance of anthropogenic emissions.
\end{abstract}

Keywords: $\mathrm{PM}_{10}$; Ions; SVOC; PAHs; Anthropogenic sources.

\section{INTRODUCTION}

\footnotetext{
* Corresponding author.

Tel.: +213-23189059

E-mail address: n.yassaa@cder.dz

** Corresponding author.

Tel.: +49-341-2717-7024; Fax: +49-341-2717-99-7023

E-mail address: herrmann@tropos.de
}

The composition of airborne particulate matter is complex and consists of a mixture of many different chemical components, which can have different natural or man-made sources (Kelly and Fussell, 2012). Recent epidemiological studies have shown that the exposure to high levels of airborne particles can have various health effects (Lippmann and Chen, 2009).

The World Health Organization (WHO) showed that 
health effects can be expected from long-term exposure to $\mathrm{PM}_{10}$. WHO guidelines support maximum mean annual concentrations of $20 \mu \mathrm{g} \mathrm{m}^{-3}\left(\mathrm{PM}_{10}\right)$ and maximum mean daily concentrations of $50 \mu \mathrm{g} \mathrm{m}^{-3}\left(\mathrm{PM}_{10}\right)$ (World Health Organization 2006). In the European Union, a maximum of 35-day exceedance of the daily limit for $\mathrm{PM}_{10}$ of $50 \mu \mathrm{g} \mathrm{m}^{-3}$ is allowed, while the average yearly limit is set at $40 \mu \mathrm{g} \mathrm{m}^{-3}$ (Directive 2008/50/EC). However, in Algeria, the limits are less stringent and the maximum value of $\mathrm{PM}_{10}$ is fixed at $80 \mu \mathrm{g} \mathrm{m}^{-3}$ (People's Democratic Republic of Algeria 2006).

To understand these effects, it is imperative to elucidate particle sources in the atmosphere by studying their chemical composition and physical properties (Borgese et al., 2012).

Water soluble ions and heavy metals are widely studied as important constituents of inorganic aerosol. Researching water-soluble ions (WSI) can help identify their main sources and formation mechanisms, because not only are particle formation, acidity, and fate directly influenced by them, they also indirectly impact ecosystems and environmental materials through deposition (Liang et al., 2016a). Out of all WSI (water-soluble ions) in fine particles, the three most abundant ions are nitrate $\left(\mathrm{NO}_{3}{ }^{-}\right)$, sulfate $\left(\mathrm{SO}_{4}{ }^{2-}\right)$, and ammonium $\left(\mathrm{NH}_{4}{ }^{+}\right)$ (Yin et al., 2014), which are usually formed by secondary processes from their precursor gases nitrogen dioxide $\left(\mathrm{NO}_{2}\right)$, sulfur dioxide $\left(\mathrm{SO}_{2}\right)$, and ammonia $\left(\mathrm{NH}_{3}\right)$ (Wang et al., 2006) Besides these three main ions, there are many other watersoluble ions, such as $\mathrm{Cl}^{-}, \mathrm{Na}^{+}, \mathrm{K}^{+}, \mathrm{Mg}^{2+}$, and $\mathrm{Ca}^{2+}$ (Bressi et al., 2013; Deshmukh et al., 2013), that form part of the inorganic particle fraction.

Trace metals comprise another fraction of inorganic particles. Based on the origin of trace metals, the various elements in particle matter can often be distinguished in anthropogenic ones (e.g., V, Cr, Mn, Ni, Cu, Zn, Cd, Pb) and natural ones (e.g., $\mathrm{Na}, \mathrm{Mg}, \mathrm{K}, \mathrm{Ca}, \mathrm{Si}, \mathrm{Al}$ ) (Contini et al., 2012). The elements $\mathrm{Cu}, \mathrm{Zn}$, and $\mathrm{Pb}$ are often associated with road dust and traffic emissions (Birmili et al., 2006), oil combustion sources are represented by $\mathrm{V}, \mathrm{Ni}$, and $\mathrm{Pb}$ (Viana et al., 2008), while $\mathrm{Cd}, \mathrm{Zn}, \mathrm{Cu}$, and $\mathrm{Hg}$ represent an important source of industrial processing of materials and nonferrous minerals (Sánchez de la Campa et al., 2011).

Saccharidic compounds are considered to be an important constituent of organic particulate matter and one of the major class of water-soluble organic compounds (Liang et al., 2016b). The anhydromonosaccharide levoglucosan is a specific biomass-burning tracer formed through the pyrolysis of cellulose and hemicellulose (Fu et al., 2016), while the sugar alcohol arabitol is a tracer for airborne fungal spores (Bauer et al., 2008).

Low molecular weight dicarboxylic acids (LMW DCA) from $\left(\mathrm{C}_{2}\right)$ to $\left(\mathrm{C}_{5}\right)$ can represent another significant fraction of water-soluble organic aerosols in the atmosphere (Kawamura and Sakaguchi, 1999), and are ubiquitous in atmospheric particles in the troposphere (Kawamura and Bikkina, 2016). Among LMW DCA, oxalic acid $\left(\mathrm{C}_{2}\right)$ is usually the most abundant, followed by either malonic $\left(\mathrm{C}_{3}\right)$ or succinic $\left(\mathrm{C}_{4}\right)$ acid (Kawamura and Bikkina, 2016). DCA can be produced by many primary sources, such as biomass burning (Legrand et al., 2007), cooking (Schauer et al., 2002), vehicular exhaust (Kawamura and Bikkina, 2016), and natural marine sources
(Rinaldi et al., 2011), while their main origins are secondary formation from different volatile organic precursor gases (van Pinxteren et al., 2014).

Semi-volatile organic compounds (SVOC), including polycyclic aromatic hydrocarbons (PAHs), hopanes, and alkanes, are one of the most studied organic pollutants in atmospheric chemistry (Wang et al., 2009; van Pinxteren et al., 2015; Liang et al., 2016a). The PAHs are carcinogens and mutagens (IARC, 2005), and are hugely associated with anthropogenic emissions from incomplete combustion of petrochemicals, biomass, tobacco, coal, and wood (Khedidji et al., 2017). In the gas-phase, PAHs generally exist for a few hours or less and they might also react chemically and photochemically in the particle phase (Oliveira et al., 2014). One compound that is distinguished among the 16 PAHs classified by U.S. EPA is benzo(a)pyrene which is considered because of its strong carcinogenicity (Srogi, 2007; Rabhi et al., 2018), equivalent toxicity (dozens of $\mathrm{ng} \mathrm{m}^{-3}$ ), and individual carcinogenicity index (several $10^{-5}$ ) (Li et al., 2012). Triterpenoid hydrocarbons, better known as hopanes, are compounds mainly derived from bacteria such as bacterioparanols and produced during a geological period through diagenesis in sediments (Oros and Simoneit, 2000).

Carbonaceous aerosols (organic and elemental) can considerably affect health, the environment, and the climate system (Liang et al., 2016a). Organic carbon (OC) can be produced through the primary emission or secondary conversion of volatile organic compounds (VOCs) into particulate matter, while elemental carbon (EC) is primary emitted through incomplete combustion (Zhu et al., 2014).

Overall, the composition of organic and inorganic particulate matter in marine aerosols in Algeria remains largely unclear, mainly due to insufficient spatio-temporal coverage of insitu measurements and the lack of identification and quantification of organic and inorganic compound species.

In the present work, the concentrations, compositions, and sources of particulate organic and inorganic constituents of $\mathrm{PM}_{10}$, including water-soluble ions, trace metals, OC, EC, sugars, dicarboxylic acids, SVOC, i.e., alkanes, PAHs, and hopanes are presented. Our study was conducted near the coastal area of Bou Ismaïl in Algeria, $35 \mathrm{~km}$ south-west from downtown Algiers.

Due to its geographical position, which covers a coastline of ca. $1622 \mathrm{~km}$, Algeria is an interesting location to study potentially toxic substances occurring in the air of hot, temperate, tropical and desert regions and provide better insights into the pathways as well as spatial and temporal scales through which contaminants are spread out over the whole Mediterranean Basin.

For this purpose, an intensive monitoring campaign was conducted for five months (September 2011-January 2012). The main aim was to study marine aerosol chemical composition in the coastal region, with a special focus on the influence of anthropogenic emissions.

The chemical composition of marine aerosol particles was combined with information regarding air mass origin and meteorological data to elucidate the characteristics of marine aerosols and to reveal their sources.

The results of this study were compared to those obtained 
elsewhere in Algeria and the Mediterranean region, and the toxicity associated with the occurrence of target compounds was assessed.

\section{EXPERIMENTAL}

\section{Description of Sampling Sites}

In order to assess the monthly and daily variations of water-soluble ions (WSI), metals, carbonaceous material, sugars, dicarboxylic acids (DCAs), and semi-volatile organic compounds (SVOCs), marine aerosol particles were collected in the coastal area of Bou Ismail from September 2011 to January 2012. The samples were taken in the open air on the campus of the Scientific and Technical Research Center in Physico-Chemical Analysis (CRAPC) (36³8'26.39"N, $2^{\circ} 43^{\prime} 6.57 \mathrm{E}$ ), situated at an altitude of $160 \mathrm{~m}$ above sea level (Fig. 1).

Fishing, agriculture, and some summer tourism are considered to be the main activities of the city. Additionally, two major industrial groups have established themselves there: paper tonic and ceramics manufacture.

Bou Ismail has experienced a long period of marine pollution caused by domestic and industrial wastewater discharges (including tonic and hippocampus). Accordingly, swimming was banned by the local authorities in 2007 .

\section{Collection Materials and Sampling Protocols}

Aerosols were collected with a medium volume sampler (MVS) model, DDA-PLOB-PD, operating at a flow rate of $39 \mathrm{~L} \mathrm{~min}^{-1}$ and equipped with a $\mathrm{PM}_{10}$ inlet and a volume counter that measured the volume of the air that passed through the quartz filter (type Munktell filter, SWEDEN, diameter $47 \mathrm{~mm}$ ).

First, the filters were placed in a filter holder and then changed manually, with a sampling time of 24 hours for weekday sampling and 72 hours for weekend sampling from Thursday to Sunday. During the five months between September 2011 and January 2012, a total of 84 filters were collected and analyzed. Additionally, several field blank filters were also collected. All filters were heated in an oven for $4 \mathrm{~h}$ at $450^{\circ} \mathrm{C}$ in order to reduce contamination before use. The filters were then stored in packs of 30 in sealed glass vials at room temperature before their use on-site in desiccator. After collection the filters were stored in the freezer at a low temperature $\left(-20^{\circ} \mathrm{C}\right)$ and were kept in the dark until chemical characterization was performed. Sample storage at low temperature $\left(-20^{\circ} \mathrm{C}\right)$ and in the dark is typically considered to minimize any potential alterations of chemical composition. All concentrations were corrected for mean blank filter values.

\section{ANALYTICAL METHODS}

Several analytical methods were applied for the chemical characterization of the samples. To determine the trace metals, three punches of $8 \mathrm{~mm}$ discs (a total of about $1.5 \mathrm{~cm}^{2}$ of the filter area) were used. In the case of organic carbon (OC) and elemental carbon (EC), a punch of $1 \mathrm{~cm}^{2}$ (about $6 \%$ of the filter area) was used, while the SVOC analysis utilized two punches of $6 \mathrm{~mm}$ discs. The remaining part of the filter was used for the analysis of ionic species, sugars, and DCAs. A description of the sample preparation can be found in Müller et al. (2010). Briefly, the remaining portion of each filter was extracted into $1.75 \mathrm{~mL}$ of ultrapure water under ultrasonic agitation for $30 \mathrm{~min}$. After extraction, the solution was filtered through a syringe filter $(0.45 \mu \mathrm{m}$, Ion Chromatography Acrodisc, Pall, NY, USA) to remove insoluble materials.

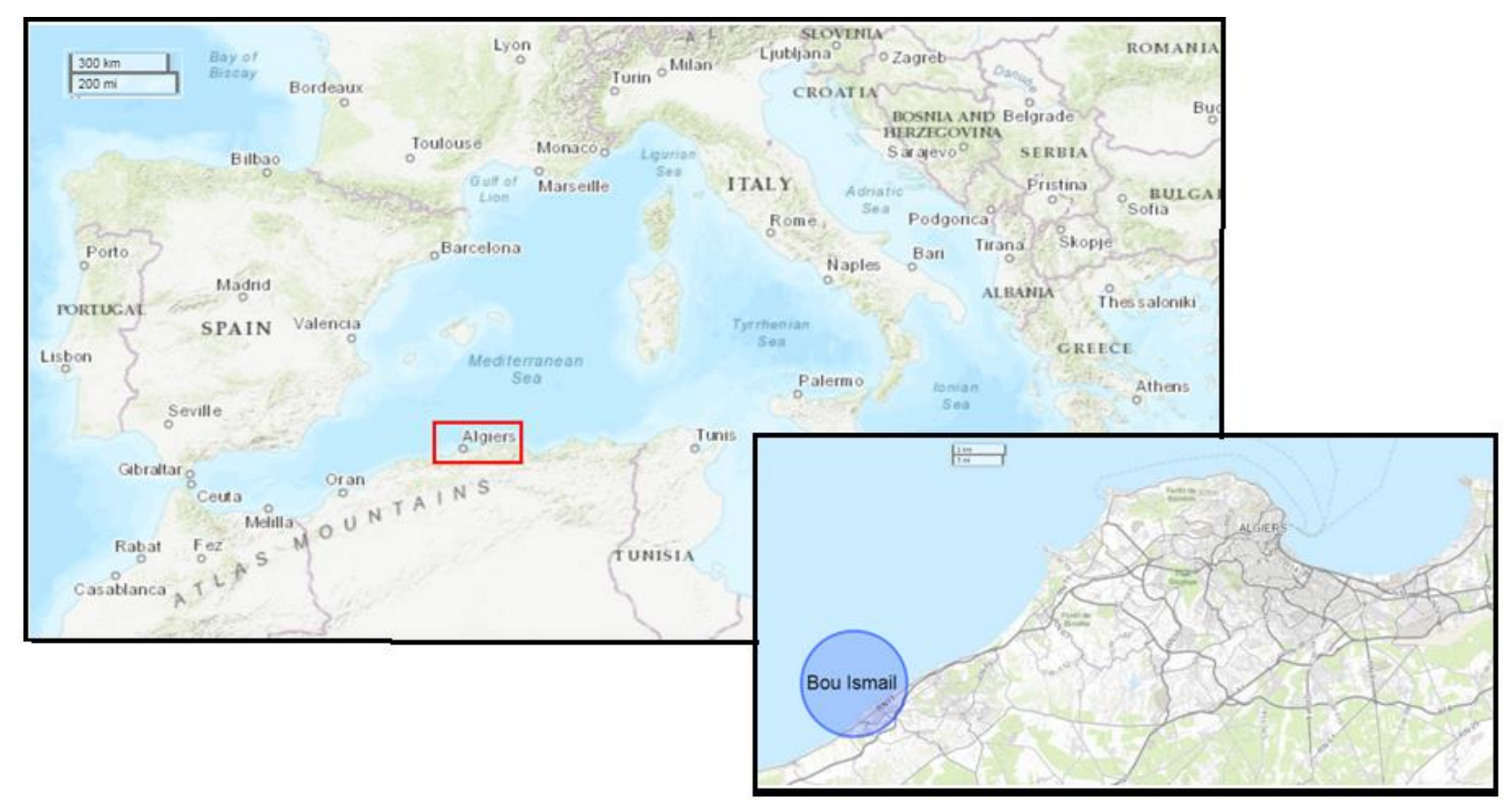

Fig. 1. General view of the Mediterranean Sea indicating sampling locations on the CRAPC campus. 


\section{Inorganic Ion Analysis}

The analysis of inorganic ions $\left(\mathrm{Cl}^{-}, \mathrm{NO}_{3}^{-}, \mathrm{SO}_{4}{ }^{2-}, \mathrm{Br}^{-}\right.$, $\mathrm{PO}_{4}{ }^{3-} \mathrm{Na}^{+}, \mathrm{NH}_{4}^{+}, \mathrm{K}^{+}, \mathrm{Mg}^{2+}$, and $\mathrm{Ca}^{2+}$ ) was performed through ion chromatography (ICS3000, Dionex) equipped with a conductivity detector and automatic production of high purity eluents. The eluent used for cations was methylsulfonic acid (MSA), while anion analysis was carried out with potassium hydroxide $(\mathrm{KOH})$. To separate cations, a combination of GC16 and CS16 columns (3 mm) was used, while AG18 and AS18 columns were applied for anions.

\section{Metal Analysis}

The elements Al, P, S, Cl, K, Ca, Ti, V, Cr, Mn, Fe, Cu, $\mathrm{Zn}, \mathrm{Ba}$, and $\mathrm{Pb}$ were determined from the quartz filter pieces using total reflection X-ray fluorescence spectroscopy (TXRF, Picofox S2, Bruker, Bremen, Germany) equipped with a Mo X-ray source on polished quartz substrates (sample holder). The $8 \mathrm{~mm}$ filter punches were digested in $0.6 \mathrm{~mL}$ of a $3: 1 \mathrm{HNO}_{3} / \mathrm{HCl}$ solution at $80^{\circ} \mathrm{C}$ to extract the elements. After digestion, the samples were cooled and aliquots of $100 \mu \mathrm{L}$ were added to the polished quartz sample holders. These were heated at $90^{\circ} \mathrm{C}$ to evaporate the liquid, and gallium was added as an internal standard. The amount of gallium applied depended on the aerosol loading of the filters (10 ng for blank filters, $100 \mathrm{ng}$ for moderately polluted samples, and $1000 \mathrm{ng}$ for heavily polluted samples). Si concentrations could not be effectively quantified due to the high Si background values of the quartz sample holder substrate. The extensive analytical procedure of trace metals can be found in Fomba et al. (2013).

\section{EC/OC Analysis}

The determination of the total carbon (TC) as organic carbon (OC) and elemental carbon (EC) was performed by a thermo-optical transmission system described in detail elsewhere (van Pinxteren et al., 2015), using a dual-optical carbon analyzer (Sunset Laboratory Inc., USA). The temperature protocol EUSAAR 2 (EUropean Supersites for Atmospheric Aerosol Research) was used and a correction for charring effects was employed. First, the sample was heated up to about $870^{\circ} \mathrm{C}$ in an inert atmosphere of pure helium. These conditions allowed the organic carbon to be volatilized and conducted in the second furnace filled with $\mathrm{Mn}_{2} \mathrm{O}$ (oxidation catalyst), where it was quantitatively oxidized into $\mathrm{CO}_{2}$. As a second step, the sample was placed in an oxidizing atmosphere (helium/oxygen), leading to the oxidation and volatilization of the refractory elemental carbon remaining on the filter.

The elemental carbon thus desorbed was also quantitatively converted into $\mathrm{CO}_{2}$ in the second furnace. The $\mathrm{CO}_{2}$ formed during the analysis was not directly measured, but passed through a methanizer in order to be converted into $\mathrm{CH}_{4}$, a species quantitatively detected by the flame ionization detector (FID).

During the first thermal step (pure helium), part of the organic carbon can pyrolyze and remain on the filter. This "Pyrolytic" carbon has properties similar to those of EC, i.e., it is refractory and absorbs light. It can only be desorbed during the second step while measuring elemental carbon and its detection can lead to an underestimation of the $\mathrm{OC}$ and an overestimation of the EC. Therefore, a correction of the pyrolysis was achieved by monitoring the absorption properties throughout the measurement (Birch and Cary, 1996; NIOSH, 1998). The correction value for pyrolytic carbon was determined by measuring the sample transmission using a laser at $678 \mathrm{~nm}$.

\section{Saccharidic Compounds Analysis}

The chemical characterization of saccharidic compounds was performed by applying a procedure described elsewhere (Iinuma et al., 2009). Selected saccharidic compounds, e.g. levoglucosan and arabitol, were analyzed using highperformance anion-exchange chromatography coupled with pulsed amperometric detection (HPAEC-PAD). The method was performed by using a Dionex ICS-3000 system consisting of SP (quaternary pump and degasser), DC (column compartment), ED (electrochemical detector and gold electrode), and EO (eluent organizer) units and an AS40 autosampler (Dionex, Sunnyvale, CA, USA).

\section{Dicarboxylic Acid Analysis}

The analysis of the DCAs oxalate $\left(\mathrm{C}_{2}\right)$, malonate $\left(\mathrm{C}_{3}\right)$, succinate $\left(\mathrm{C}_{4}\right)$, malate $\left(\mathrm{C}_{4}\right)$, and glutarate $\left(\mathrm{C}_{5}\right)$ was carried out through capillary electrophoresis (Spectra Phoresis 1000, Thermo Separation Products, Germany) of the aqueous filter extract. The separation was performed in a fused silica capillary of $70 \mathrm{~cm}(63 \mathrm{~cm}$ to the detector) with an internal diameter of $75 \mu \mathrm{m}$. The background electrolyte was composed

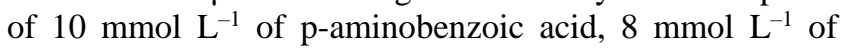
diethylenetriamine, and $3.5 \mathrm{mmol} \mathrm{L} \mathrm{m}^{-1}$ of aqueous sodium hydroxide ( $\mathrm{pH}=9.6$ ) (van Pinxteren et al., 2014).

\section{Analysis of the SVOCs by CPP-GC/MS}

Analyses of selected semi-volatile organic species, namely n-alkanes, polycyclic aromatic hydrocarbons (PAHs), hopanes, and ketones, were carried out using a Curie-point pyrolyzer (JPS-350, JAI Inc., Japan) coupled with a GC-MS system (6890 N GC, 5973 inert MSD, Agilent Technologies, CA, USA).

The filter aliquots were spiked with a solution of internal standards, including perdeuterated tetracosane- $\mathrm{d}_{10}\left(\mathrm{C}_{24}\right.$ $\left.\mathrm{D}_{50}\right)$, dotriacontane- $\mathrm{d}_{66}\left(\mathrm{C}_{32}-\mathrm{D}_{66}\right)$, acenaphthene- $\mathrm{d}_{10}\left(\mathrm{C}_{12}-\right.$ $\left.D_{10}\right)$, phenanthrene- $d_{10}\left(C_{14}-D_{10}\right)$, chrysene- $d_{12}\left(C_{18}-D_{12}\right)$, perylene- $d_{12}\left(C_{20}-D_{12}\right)$, and coronene- $d_{12}\left(C_{24}-D_{12}\right)$. The two punches of each filter were then covered by an alloy of iron and nickel $(50 \% \mathrm{Fe} ; 50 \% \mathrm{Ni})$ and vaporized instantly in a pyrolysis chamber at $510^{\circ} \mathrm{C}$ for $4 \mathrm{~s}$ in a helium atmosphere (Scheinhardt et al., 2013).

A separation of different species was performed using a capillary column coated with a stationary phase of $5 \%$ phenylarylene and $95 \%$ dimethylpolysiloxane (ZB-5MS, $30 \mathrm{~m}$ long, $0.25 \mathrm{~mm}$ internal diameter, film thickness of $0.25 \mu \mathrm{m}$, Phenomenex). The column temperature was held at $50^{\circ} \mathrm{C}$ for $5 \mathrm{~min}$, then raised to $200^{\circ} \mathrm{C}$ at $+20^{\circ} \mathrm{C} \mathrm{min}^{-1}$ and kept constant for $5 \mathrm{~min}$; a second ramp $\left(+12^{\circ} \mathrm{C} \mathrm{min}^{-1}\right.$ rate $)$ heated the column up to $310^{\circ} \mathrm{C}$, where elution was completed within $10 \mathrm{~min}$. The mass spectrometer system was operated in electron impact mode (ion source energy $=70 \mathrm{eV}$ ), and the 
GC/MS data was acquired by a dedicated software (ChemStation) purchased from Agilent.

A second mixture of compounds containing n-alkanes $\left(\mathrm{C}_{20}-\mathrm{C}_{34}\right.$, plus phytane and pristane), PAHs and their derivatives, hopanes, and n-alkan-2-ones $\left(\mathrm{K}_{15}-\mathrm{K}_{19}\right)$ was included for each series of analyses.

An analysis of more than 84 aerosol samples collected in a coastal area near Bou Ismail enabled the identification and quantification of 56 semi-volatile organic compounds (17 n-alkanes, 19 PAHs, 3 Me-PAHs, 3 OPAHs, 9 hopanes, and 5 n-alkan-2-one) during the period from September 2011 to January 2012. The concentrations of individual organics measured over the whole campaign can be found in the Supplementary Information (Table S1).

These elements were identified using the mass spectral library, which usually supplied by the concessionaire. It is to note that the library presented a lack of data in regard to the chemical composition of atmospheric aerosols. In this case standards are often required.

\section{Quality Control/Quality Assurance}

The analytical features of the method used for the analysis of the previously assigned classes were already reported in the framework of previous studies (Iinuma et al., 2009; Müller et al., 2010; Scheinhardt et al., 2013; van Pinxteren et al., 2014; Fomba et al., 2018). Nevertheless, new tests were carried out in order to verify the efficiency, recovery, repeatability and reproducibility. Both clean filters spiked with $20 \mathrm{ng}$ of native standards and real aerosol samples were submitted to analysis after the usual sample preparation.

To assess the analyte recovery, three sets, each including three samples, were kept from a homogeneous matrix and analysed as follows: The first set (X) was fortified with $25 \mathrm{ng}$ of native standards and internal standard and was injected directly in the pyrolysis chamber of the GC-MS system. The second one (Y) was fortified with $5 \mathrm{ng}$ internal standard onto the samples just before GC injection. The third set (Z) was processed without special treatment as a control group. The average concentrations from the $\mathrm{Y}$ set divided by those from $\mathrm{X}$ yielded the percent recovery values $[100 \times(\mathrm{Y} / \mathrm{X})=\%$ recovery] for all analyte compounds.

Comparing the results from each aliquot of $\mathrm{X}$ and $\mathrm{Z}$ groups, the average repeatability was calculated; reproducibility was evaluated by comparing the results in each set and among sets. The analytical quality control parameter values are reported in Table $\mathrm{S} 2$.

The total PAH recoveries were in the range of $71.2 \%$ (Retene) and $96.4 \%$ (Chrysene). In the case of n-alkanes, the calculated recovery among all homologues was equal to 70 $80 \%$. The large variability associated with the recoveries of the PAHs was due to the presence of large differences between compounds. Among all PAHs recoveries, the lower value found for fluorene (FA) was likely owed to the high volatility of the substance.

\section{METEOROLOGICAL INFORMATION AND CLASSIFICATION OF SAMPLING DAYS}

The daily temperature, wind speed, and rainfall were continuously measured at a station of the national office of meteorology ( $25 \mathrm{~km}$ east of the sampling site).

Temporal variations during the measuring period were classified based on two seasons of the year, fall (September until November; Fa) and winter (December until January; Wi), which were divided into five weeks per month. Temperature and wind speed were calculated as average weekly values, while for rainfall the weekly sum was calculated.

Rainfall values were found to be between $1 \mathrm{~mm}$ and $84.9 \mathrm{~mm}$ during fall, as well as $2 \mathrm{~mm}$ and $33 \mathrm{~mm}$ in the winter. The temperature varied between $15^{\circ} \mathrm{C}$ and $23^{\circ} \mathrm{C}$ during fall and between $9.6^{\circ} \mathrm{C}$ and $14^{\circ} \mathrm{C}$ in the winter. The highest average wind speed was on September 2011-Week 5 (W5) $\left(37.5 \mathrm{~km} \mathrm{~h}^{-1}\right)$ and the lowest was on November 2011W5 $\left(13 \mathrm{~km} \mathrm{~h}^{-1}\right)$.

A classification of the sampling days and meteorological conditions is given in the Supplementary Information (Table S3).

The origin of the sampled air masses was determined from 48-hour back-trajectories were obtained with the NOAA Hysplit model (Draxler and Rolph, 2003) (http://ready.arl.n oaa.gov/hysplit-bin/trajtype.pl). Days with an air-mass transport from the northwest or northeast sector were considered to be maritime-influenced, whereas days with an air mass from the southeast or southwest sector were mostly influenced by mineral dust. Out of the 21 sampling weeks (equivalent to 124 sampling days), sixteen have an air mass origin in the marine sector. The back trajectories used to define the different types of air masses (marine or dust) sampled at Bou Ismaill are shown in the Supplementary Information (Fig. S1). For each of the sampling periods, only one back trajectory was selected as a representative of the whole week.

Most sampling periods show that the air masses crossed Spain and France towards the Mediterranean Sea, except for the samples from October 2011-W4, October 2011-W5, November 2011-W1, November 2011-W5, and December 2011-W1, which were from the dust influenced sector. The air masses of the marine samples have rather similar origins, and followed an essentially marine path before reaching the sampling site in the north.

\section{RESULTS AND DISCUSSION}

\section{Weekly Variations of PM10 Chemical Compositions and Trends of Meteorological Conditions}

Fig. 2 shows the relationships between the weekly averaged concentrations of individual ions, trace metals, EC/OC, sugars, DCAs, and SVOCs. As the samples are spread over the two seasons fall and winter under varying weather conditions such as temperature and rainfall, this allows for an examination of the temporal variability of the concentrations and their connection with meteorological conditions and air mass origin. It is observed that the concentrations can strongly vary over the weekly periods. In both seasons, the average weekly temperatures varied from a minimum value of $17^{\circ} \mathrm{C}$ up to a maximum of $31^{\circ} \mathrm{C}$, with mean values of $26.2^{\circ} \mathrm{C}$ in fall and $20^{\circ} \mathrm{C}$ in winter. Throughout the sampling campaign, the sums of the weekly rainfall 


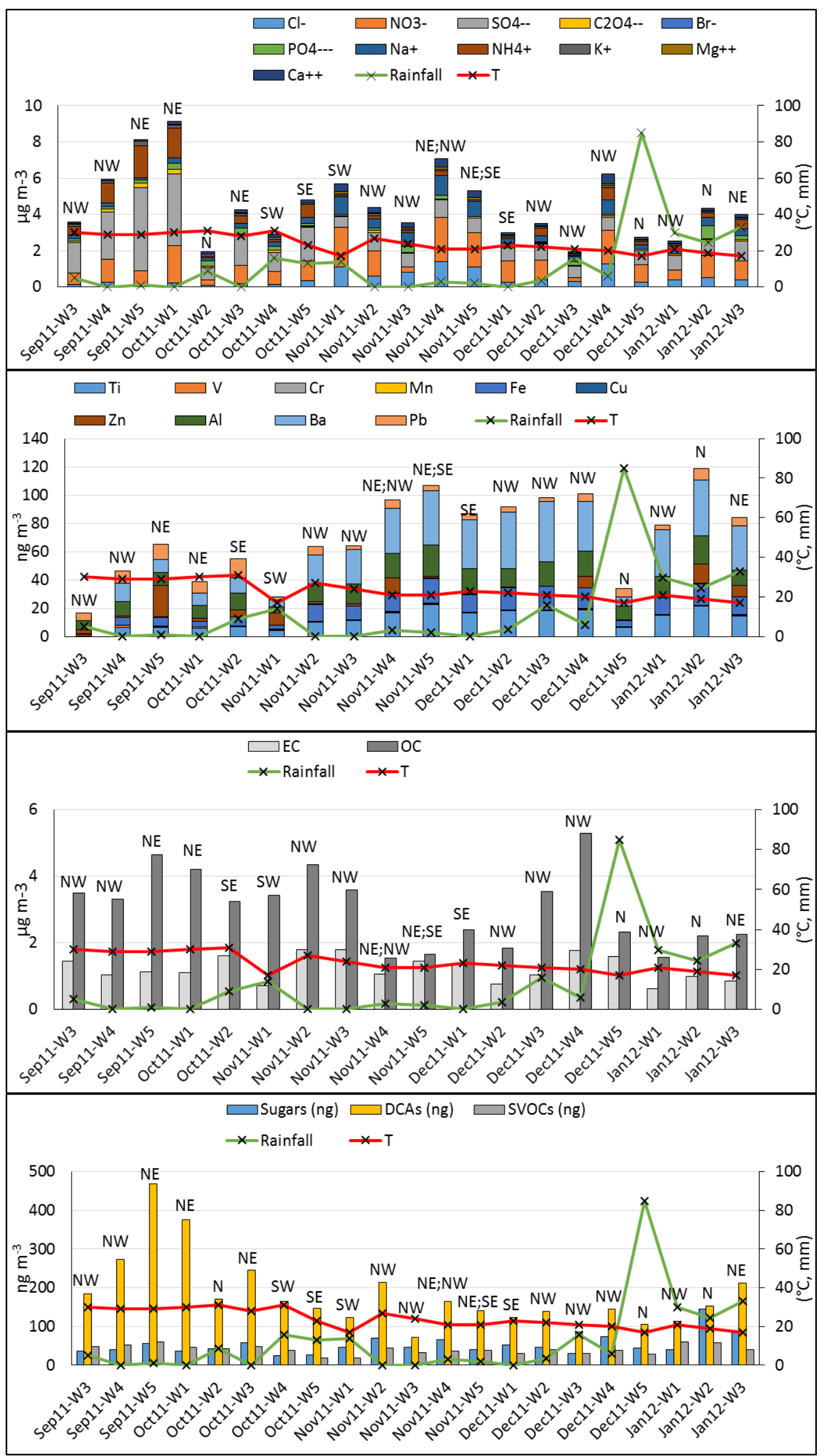

Fig. 2. Weekly relationship between the concentrations of individual ions, trace metals, EC/OC, sugars, DCAs, and SVOCs. 
reached a maximum of $84.9 \mathrm{~mm}$ and almost no rainfall was registered for 6 weeks of the campaign. Based on this former observation of meteorological data, two seasons could be distinguished, higher temperature (September-November) and lower temperature (December and January). Overall, the maximum concentrations of the different constituents were obtained during low precipitation periods, whereas the minimum concentrations occurred during periods of high precipitation. Similar to the findings in this work, Han et al. (2009) found that heavy rainfall would reduce concentrations of anthropogenic aerosols in summer.

In both seasons, a similar situation was observed regarding the total concentrations of inorganic ions, EC/OC, and SVOCs, while the trace metal levels were, on average, higher in winter than in fall. Contrary to trace metals, the concentrations of DCAs were found to be higher in fall than in winter. This finding goes hand in hand with the influence of photochemical reactions on the production of DCAs in the warm season, whereas the strong concentration of metal elements in the cold season could be explained by an anthropogenic origin from heating processes. The temporal variability has been well demonstrated by these former compound groups. Moreover, the northern air mass origin was more significant in winter than in fall while the southeastern or southwestern emissions by the Sahara dust are assumed to be more important during the warm period. In total, the highest level of all compounds was found in the NE and NW categories with no or less rain during the week, and the lowest concentrations were found in the warm weeks and S categories.

\section{Monthly Variations of PM10 Constituents}

The monthly mean concentrations of the inorganic and organic compounds observed in the aerosol particles in Bou Ismaïl are reported in Table 1.

The average concentrations of the determined constituents are strongly dependent on the intensity of their source emissions, weather conditions, and dispersion and deposition processes. All these conditions are generally very variable on a given site throughout the year, which can lead to seasonal cycles.

\section{Water-soluble Ions (WSI)}

The inorganic ion concentrations of $\mathrm{PM}_{10}$ during the campaign are summarized in Table 1. Total ion concentrations varied between $3.62 \mu \mathrm{g} \mathrm{m}^{-3}$ in December and $5.20 \mu \mathrm{g} \mathrm{m}^{-3}$ in September. The bulk $(65 \%)$ of the ionic material mass was made up of $\mathrm{SO}_{4}{ }^{2-}, \mathrm{NO}_{3}{ }^{-}$, and $\mathrm{NH}_{4}{ }^{+}$, while the other determined ions contributed to the rest of the mass.

Out of all measured ionic species, sulfate was the most abundant ion, with concentrations between $0.74 \mu \mathrm{g} \mathrm{m}^{-3}$ (December) and $2.44 \mu \mathrm{g} \mathrm{m}^{-3}$ (September). The highest concentration of $\mathrm{SO}_{4}{ }^{2-}$ in fall, which is comparable to that in winter, is most likely caused by the photochemical oxidation reaction of $\mathrm{SO}_{2}$, accelerated by high temperatures and strong solar radiation (Sun et al., 2004; Wang et al., 2005; Zhao et al., 2013). The mass concentrations of $\mathrm{NH}_{4}{ }^{+}$ranged from $0.15 \mathrm{ng} \mathrm{m}^{-3}$ to $1.92 \mu \mathrm{g} \mathrm{m}^{-3}$ and showed their highest average in the atmosphere during fall. This finding can be explained by the conversion of gaseous $\mathrm{NH}_{3}$ to aqueous $\mathrm{NH}_{4}{ }^{+}$and depends on the concentration of acids in the atmosphere, temperature, and water availability, as well as the flux rates of $\mathrm{NH}_{3}$ which likely favoured $\mathrm{NH}_{4}{ }^{+}$formation in fall. The concentrations of $\mathrm{NO}_{3}{ }^{-}$, were between 0.95 and $1.52 \mu \mathrm{g} \mathrm{m}^{-3}$, with higher values in fall than in winter, suggesting that $\mathrm{NO}_{3}{ }^{-}$ was formed in acidic and ammonium-poor environments as reported in a previous study in Beijing, China (Xiang et al., 2017). Also, ammonium-poor conditions were defined as $\left[\mathrm{NH}_{4}{ }^{+}\right] /\left[\mathrm{SO}_{4}{ }^{2-}\right]<1.5$ (Pathak et al., 2011). In our study, the value of this ratio was low (i.e., 0.31 on average) suggesting the acidic nature of the aerosol and generally an ammoniumpoor environment.

The distribution patterns of concentration time series of inorganic ions are shown in Fig. 3.

Comparing the profiles of $\mathrm{NH}_{4}{ }^{+}$and $\mathrm{SO}_{4}{ }^{2-}$ on the one hand and $\mathrm{Cl}^{-}$and $\mathrm{Na}^{+}$on the other hand seemed to have similar distribution, suggesting that these species were overall released by the same sources.

The higher concentrations of chloride and sodium were found in winter with maximum values of 4.11 and 2.77 $\mu \mathrm{g} \mathrm{m}^{-3}$, respectively.

The concentrations of sulfate, nitrate and ammonium obtained in this study on the coast of Bou Ismail and in other areas in the Mediterranean Sea are shown in Table 2. The observed concentrations in this study are lower than those measured in the atmospheres of Marseille (El Haddad et al., 2009), Zagreb (Perrone et al., 2018), Antalya (Öztürk et al., 2012), the harbor of Barcelona (Pey et al., 2013), and rural Finakolia in Greece (Li et al., 2013). They are of the same order of magnitude as those recorded at the urban site of Oporto (Custódio et al., 2016).

However, there is some difficulty when comparing the concentrations obtained in those few studies, since the ion ranges are not comparable on every site.

For instance, Benchrif et al. (2018) reported lower concentration ranges of ions such as $\mathrm{SO}_{4}{ }^{2-}$ and $\mathrm{NH}_{4}{ }^{+}$at Tetouan in northern Morocco, with average values of $0.41 \mu \mathrm{g} \mathrm{m}^{-3}$ and $0.31 \mu \mathrm{g} \mathrm{m}^{-3}$, respectively, but mentioned higher values of $\mathrm{NO}_{3}{ }^{-}\left(1.45 \mu \mathrm{g} \mathrm{m}^{-3}\right)$. Results obtained by Galindo et al. (2017) on the mountain Aitana in Spain showed lower mean concentrations of $\mathrm{NO}_{3}{ }^{-}\left(0.82 \mu \mathrm{g} \mathrm{m}^{-3}\right)$ and $\mathrm{NH}_{4}{ }^{+}\left(0.39 \mu \mathrm{g} \mathrm{m}^{-3}\right)$, but higher ones of $\mathrm{SO}_{4}{ }^{2-}\left(1.5 \mu \mathrm{g} \mathrm{m}^{-3}\right)$, when compared to the present study. Anions such as $\mathrm{NO}_{3}{ }^{-}$ and $\mathrm{SO}_{4}{ }^{2-}$ had higher mean concentrations than those reported by Pietrogrande et al. (2018) at the central Mediterranean site Salento in Italy, but the cation $\mathrm{NH}_{4}{ }^{+}$had an average concentration comparable to our results.

\section{Metal Elements}

Fig. 4 and Table 1 depict the daily variations of all trace metals measured in the field campaign. The total trace metal concentrations varied between $16 \mathrm{ng} \mathrm{m}^{-3}$ and $143 \mathrm{ng} \mathrm{m}^{-3}$. Out of the ten trace metals identified in the atmosphere of Bou Ismaïl, barium $(\mathrm{Ba})$, titanium $(\mathrm{Ti})$, aluminum $(\mathrm{Al})$, and iron (Fe) are the most abundant metal elements, with average daily concentrations of $32.1 \mathrm{ng} \mathrm{m}^{-3}\left(4.67-57 \mathrm{ng} \mathrm{m}^{-3}\right), 15.5$ $\mathrm{ng} \mathrm{m}^{-3}\left(0.44-29.6 \mathrm{ng} \mathrm{m}^{-3}\right), 15 \mathrm{ng} \mathrm{m}^{-3}$ (4.08-36.4 $\left.\mathrm{ng} \mathrm{m}^{-3}\right)$, and $12.6 \mathrm{ng} \mathrm{m}^{-3}\left(0.56-24.4 \mathrm{ng} \mathrm{m}^{-3}\right)$, respectively. Barium is a major element in the air around Bou Ismail and represents 
Table 1. Concentrations of inorganic and organic constituents of $\mathrm{PM}_{10}$ (average, standard deviation, SD) collected during the campaign (2011-2012) in Bou Ismail $(n=84)$.

\begin{tabular}{|c|c|c|c|c|c|c|c|c|c|c|}
\hline \multirow{2}{*}{ Compounds } & \multicolumn{2}{|c|}{ September $(\mathrm{n}=10)$} & \multicolumn{2}{|c|}{ October $(n=22)$} & \multicolumn{2}{|c|}{ November $(\mathrm{n}=18)$} & \multicolumn{2}{|c|}{ December $(\mathrm{n}=20)$} & \multicolumn{2}{|c|}{ January $(n=14)$} \\
\hline & Average & SD & Average & $\mathrm{SD}$ & Average & SD & Average & SD & Average & SD \\
\hline \multicolumn{11}{|l|}{ Ions $\left(\mu \mathrm{g} \mathrm{m}^{-3}\right)$} \\
\hline $\mathrm{Cl}^{-}$ & 0.19 & 0.10 & 0.18 & 0.15 & 0.99 & 0.92 & 0.56 & 0.86 & 0.42 & 0.17 \\
\hline $\mathrm{NO}_{3}^{-}$ & 0.95 & 0.57 & 1.02 & 0.93 & 1.52 & 2.10 & 1.11 & 1.60 & 0.97 & 1.03 \\
\hline $\mathrm{SO}_{4}{ }^{2-}$ & 2.44 & 1.24 & 1.82 & 1.34 & 0.85 & 0.23 & 0.74 & 0.28 & 0.91 & 0.37 \\
\hline $\mathrm{Br}^{-}$ & 0.01 & 0.003 & 0.01 & 0.002 & 0.01 & 0.004 & 0.01 & 0.003 & 0.01 & 0.003 \\
\hline $\mathrm{PO}_{4}^{3-}$ & 0.13 & 0.09 & 0.27 & 0.13 & 0.19 & 0.16 & 0.13 & 0.12 & 0.33 & 0.69 \\
\hline $\mathrm{Na}^{+}$ & 0.19 & 0.07 & 0.27 & 0.10 & 0.82 & 0.66 & 0.42 & 0.57 & 0.38 & 0.27 \\
\hline $\mathrm{NH}_{4}^{+}$ & 0.90 & 0.59 & 0.57 & 0.68 & 0.15 & 0.17 & 0.29 & 0.51 & 0.29 & 0.28 \\
\hline $\mathrm{K}^{+}$ & 0.14 & 0.06 & 0.14 & 0.06 & 0.10 & 0.05 & 0.08 & 0.04 & 0.08 & 0.02 \\
\hline $\mathrm{Mg}^{2+}$ & 0.02 & 0.005 & 0.03 & 0.01 & 0.10 & 0.08 & 0.05 & 0.08 & 0.04 & 0.01 \\
\hline $\mathrm{Ca}^{2+}$ & 0.10 & 0.02 & 0.14 & 0.06 & 0.36 & 0.27 & 0.22 & 0.29 & 0.15 & 0.05 \\
\hline \multicolumn{11}{|l|}{ Metals (ng m ${ }^{-3}$ ) } \\
\hline $\mathrm{Al}$ & 8.58 & 1.99 & 10.66 & 1.66 & 14.46 & 9.14 & 15.83 & 8.48 & 14.03 & 6.81 \\
\hline $\mathrm{Ti}$ & 4.26 & 3.3 & 6.45 & 0.67 & 14.77 & 7.32 & 17.35 & 7.33 & 16.97 & 6.23 \\
\hline $\mathrm{V}$ & 0.99 & 0.53 & 0.63 & 0.31 & 0.41 & 0.18 & 0.38 & 0.18 & 0.49 & 0.19 \\
\hline $\mathrm{Cr}$ & 0.12 & 0.13 & 0.11 & 0.04 & 0.25 & 0.14 & 0.30 & 0.23 & 0.27 & 0.16 \\
\hline $\mathrm{Mn}$ & 0.02 & 0.03 & 0.00 & 0.00 & 0.28 & 0.37 & 0.10 & 0.30 & 0.01 & 0.02 \\
\hline $\mathrm{Fe}$ & 4.01 & 3.02 & 4.99 & 1.86 & 12.15 & 5.87 & 14.39 & 6.50 & 13.28 & 4.97 \\
\hline $\mathrm{Cu}$ & 0.23 & 0.14 & 0.13 & 0.14 & 0.20 & 0.39 & 0.02 & 0.07 & 0.04 & 0.12 \\
\hline $\mathrm{Zn}$ & 8.78 & 11.6 & 3.5 & 2.03 & 6.36 & 12.33 & 2.17 & 4.36 & 8.27 & 9.01 \\
\hline $\mathrm{Ba}$ & 7.41 & 6.64 & 9.62 & 1.69 & 28.20 & 14.94 & 36.66 & 16.81 & 34.73 & 12.46 \\
\hline $\mathrm{Pb}$ & 8.20 & 2.66 & 10.64 & 3.57 & 4.76 & 3.75 & 3.91 & 2.10 & 5.91 & 3.25 \\
\hline $\mathrm{OC}\left(\mu \mathrm{g} \mathrm{m}^{-3}\right)$ & 3.51 & 0.86 & 3.72 & 1.12 & 2.90 & 1.29 & 3.01 & 1.48 & 1.98 & 0.38 \\
\hline $\mathrm{EC}\left(\mu \mathrm{g} \mathrm{m}^{-3}\right)$ & 1.21 & 0.38 & 1.36 & 0.60 & 1.33 & 0.58 & 1.21 & 0.55 & 0.93 & 0.40 \\
\hline $\mathrm{TC}\left(\mu \mathrm{g} \mathrm{m}^{-3}\right)$ & 4.73 & 1.07 & 5.08 & 1.44 & 4.23 & 1.54 & 4.22 & 1.91 & 2.90 & 0.74 \\
\hline Levoglucosan $\left(\mathrm{ng} \mathrm{m}^{-3}\right)$ & 38.5 & 17.8 & 38.1 & 19.5 & 51.3 & 32.9 & 47.9 & 28.5 & 92.1 & 55.3 \\
\hline Arabitol $\left(\mathrm{ng} \mathrm{m}^{-3}\right)$ & 1.27 & 0.84 & 1.21 & 0.59 & 4.78 & 5.08 & 2.16 & 4.07 & 1.67 & 0.90 \\
\hline \multicolumn{11}{|l|}{ DCAs $\left(\mathrm{ng} \mathrm{m}^{-3}\right)$} \\
\hline Oxalate & 229.35 & 85.34 & 199.6 & 97.9 & 108.92 & 47.25 & 100.46 & 38.9 & 123.37 & 29.4 \\
\hline Malonate & 9.16 & 3.6 & 5.79 & 4.16 & 20.23 & 21.64 & 8.06 & 11.59 & 5.53 & 1.7 \\
\hline Succinate & 8.96 & 5.05 & 5.79 & 2.79 & 20.53 & 18.52 & 6.40 & 8.06 & 10.27 & 9.07 \\
\hline Glutarate & 9.15 & 8.22 & 9.37 & 6.94 & 7.76 & 10.35 & 4.65 & 3.68 & 7.75 & 4.45 \\
\hline Malate & n.d & n.d & n.d & n.d & 18.5 & 16.07 & 12.85 & n.d & 2.93 & 1.05 \\
\hline \multicolumn{11}{|l|}{ SVOCs $\left(\mathrm{ng} \mathrm{m}^{-3}\right)$} \\
\hline n-AlKanes & 38.3 & 11.6 & 29.9 & 10.5 & 20.1 & 10.2 & 19.5 & 7.1 & 30.9 & 14.8 \\
\hline PAHs & 8.30 & 1.91 & 8.05 & 1.95 & 9.52 & 4.56 & 9.35 & 3.7 & 14.9 & 6.87 \\
\hline Hopanes & 0.44 & 0.08 & 0.42 & 0.12 & 0.36 & 0.16 & 0.33 & 0.12 & 0.55 & 0.19 \\
\hline Alkan-2-ones & 4.47 & 2.73 & 4.68 & 2.06 & 4.24 & 2.22 & 5.79 & 3.83 & 6.18 & 3.00 \\
\hline
\end{tabular}

$37.6 \%$ of the total average concentrations of the Ten elements studied.

Based on the main sources and concentration levels, the metals can be subdivided into two groups: First, there are crustal elements with high concentrations that originate from dust, such as $\mathrm{Al}, \mathrm{Ti}, \mathrm{Mn}, \mathrm{Fe}$, and $\mathrm{Ba}$, while the second group $(\mathrm{V}, \mathrm{Cr}, \mathrm{Zn}, \mathrm{Cu}$, and $\mathrm{Pb}$ ) can overall be attributed to elements emitted by vehicular (fuel, combustion, brake, and tire abrasion) and industrial sources (Pey et al., 2010). It is to note that $\mathrm{Fe}$ and $\mathrm{Mn}$ can both be emitted by other sources, such as road traffic and fossil fuel emissions, respectively (Fomba et al., 2018).

In this study, the elements of the first group ( $\mathrm{Ba}, \mathrm{Ti}, \mathrm{Al}$, and $\mathrm{Fe}$ ) have consistently been found to be the most abundant metals originating from dust and they have attributed approximately $70 \%$ to the total concentration. Out of the elements that belong to the second group $(\mathrm{Zn}, \mathrm{Cu}, \mathrm{Cr}, \mathrm{V}$, and $\mathrm{Pb}$ ), most of which are considered to be carcinogenic (Satsangi et al., 2014), zinc ( $\mathrm{Zn}$ ) showed the highest concentration at $8.2 \mathrm{ng} \mathrm{m}^{-3}$ and copper $(\mathrm{Cu})$ the lowest at $0.22 \mathrm{ng} \mathrm{m}^{-3}$.

The individual metals displayed quite similar trends and orders of magnitude during fall and winter, except for copper $\mathrm{Cu}$. The concentration of $\mathrm{Cu}$ was between $0.001 \mathrm{ng} \mathrm{m}^{-3}$ and $1.22 \mathrm{ng} \mathrm{m}^{-3}$ and was by a factor of 4 higher in fall than in winter. These results were in agreement with another study carried out in Chinese coastal area by Cheng et al. (2012) where no significant effect of seasonal variation on concentrations of some metals was found.

The mean concentrations of $\mathrm{Pb}$ were higher (0.96-13.2

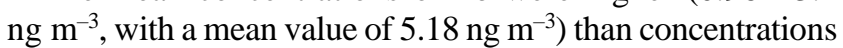



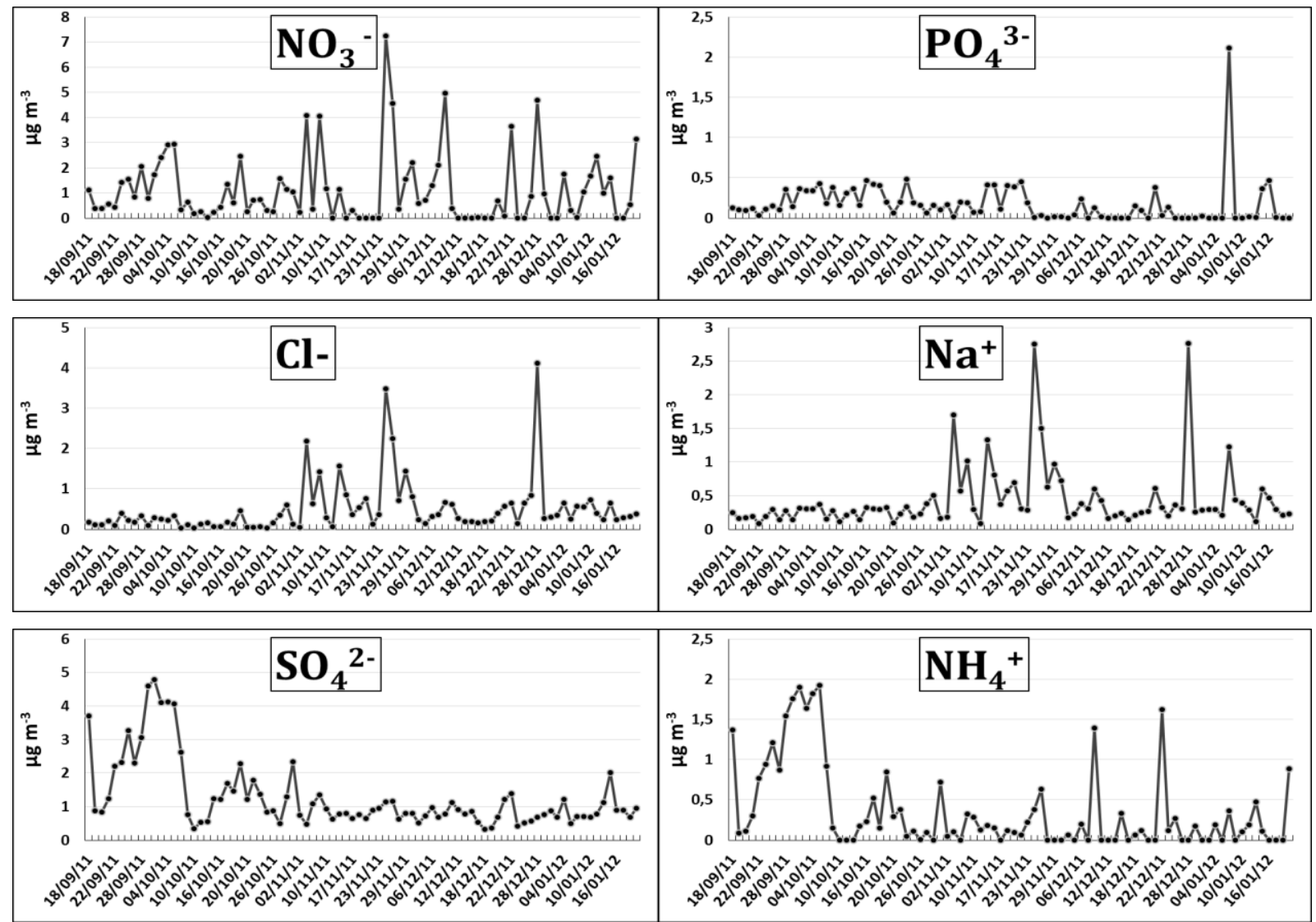

Fig. 3. Concentration time series of the main ions measured at Bou Ismail (2011-2012).

reported on other sites located in the Mediterranean Sea, such as Aitana in Spain (Galindo et al., 2017). However, they were by a factor of 3 lower than the concentrations reported by Pietrogrande et al. (2018) in Salento in Italy. The concentration ranges of this metal were within the same order of magnitude as those reported at the harbor of Barcelona (Pey et al., 2013) and on sites in urban Zagreb (Perrone et al., 2018). The concentrations of $\mathrm{Pb}$ reveal that emissions are not yet subjected to any sort of control by public authorities and are suspected to still affect the air quality on both a local and a regional scale. Because of this, the authorities must work on phasing out leaded gasoline and improving technological processes that are related to $\mathrm{Pb}$ emissions.

\section{Organic Carbon (OC) and Elemental Carbon (EC)}

The concentrations of the carbonaceous material content of the $\mathrm{PM}_{10}$ measured at the coast of Bou Ismail can be found in Table 1.

In this study, the daily average $\mathrm{OC}$ concentrations were between 0.94 to $5.53 \mu \mathrm{g} \mathrm{m}^{-3}$, while the average concentrations of EC were between 0.41 to $2.85 \mu \mathrm{g} \mathrm{m}^{-3}$. Therefore, TC concentrations ranged from 1.72 to $8.02 \mu \mathrm{g} \mathrm{m}^{-3}$.

Overall, the evolutions of OC and EC concentrations follow a very similar monthly cycle throughout the investigated period (Fig. 5). Nevertheless, the average concentrations recorded in October were slightly high, with average values of $3.72 \mu \mathrm{g} \mathrm{m}^{-3}$ for OC and $1.36 \mu \mathrm{g} \mathrm{m}^{-3}$ for $\mathrm{EC}$, while the minimum values were obtained in January, with the values
$\mathrm{EC}=0.93 \mu \mathrm{g} \mathrm{m}^{-3}$ and $\mathrm{OC}=1.98 \mu \mathrm{g} \mathrm{m}^{-3}$.

In order to evaluate the level of carbonaceous material, a comparison of the Bou Ismail EC-OC values with other studies in the Mediterranean Sea can be seen in Table 2. The concentrations measured on the Bou Ismail site were higher than those recorded in Tetouan in Northern Morocco (Benchrif et al., 2018) and Aitana in Spain (Galindo et al., 2017) but lower than the concentrations reported in Oporto, Portugal (Custódio et al., 2016), Barcelona, Spain (Pey et al., 2013), Marseille, France (El Haddad et al., 2009), Salento, Italy (Pietrogrande et al., 2018), and on a semi-urban site in Beirut, Lebanon (Waked et al., 2014). However, these values are comparable to those observed in rural locations in Finakolia, Greece (Li et al., 2013).

\section{Sugars}

Two compounds known as the anhydrosaccharide levoglucosan and the saccharide alcohol arabitol were measured between September 2011 and January 2012 in particle samples from Bou Ismaïl. Their monthly and daily average concentrations throughout the campaign are listed in Table 1 and displayed in Fig. 6.

Levoglucosan can be utilized as a specific indicator for the presence of biomass burning emissions in aerosol particulate matter, while arabitol has been used to estimate primary biological aerosol particles, such as pollen, fungal spores, vegetative debris, viruses, and bacteria (Bauer et al., 2008; Fu et al., 2012). These different sources are supported 
Khedidji et al., Aerosol and Air Quality Research, 20: 2448-2473, 2020

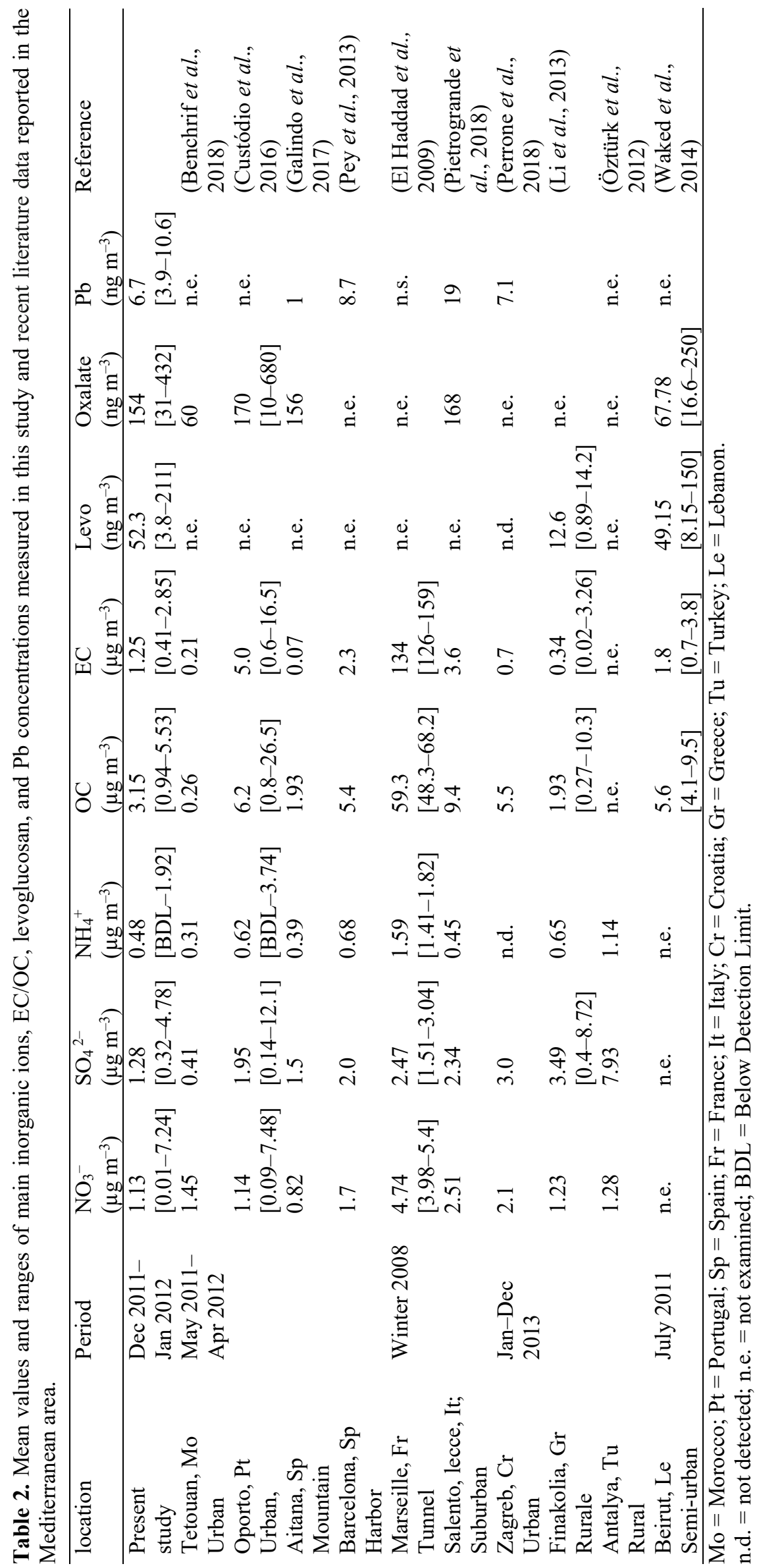



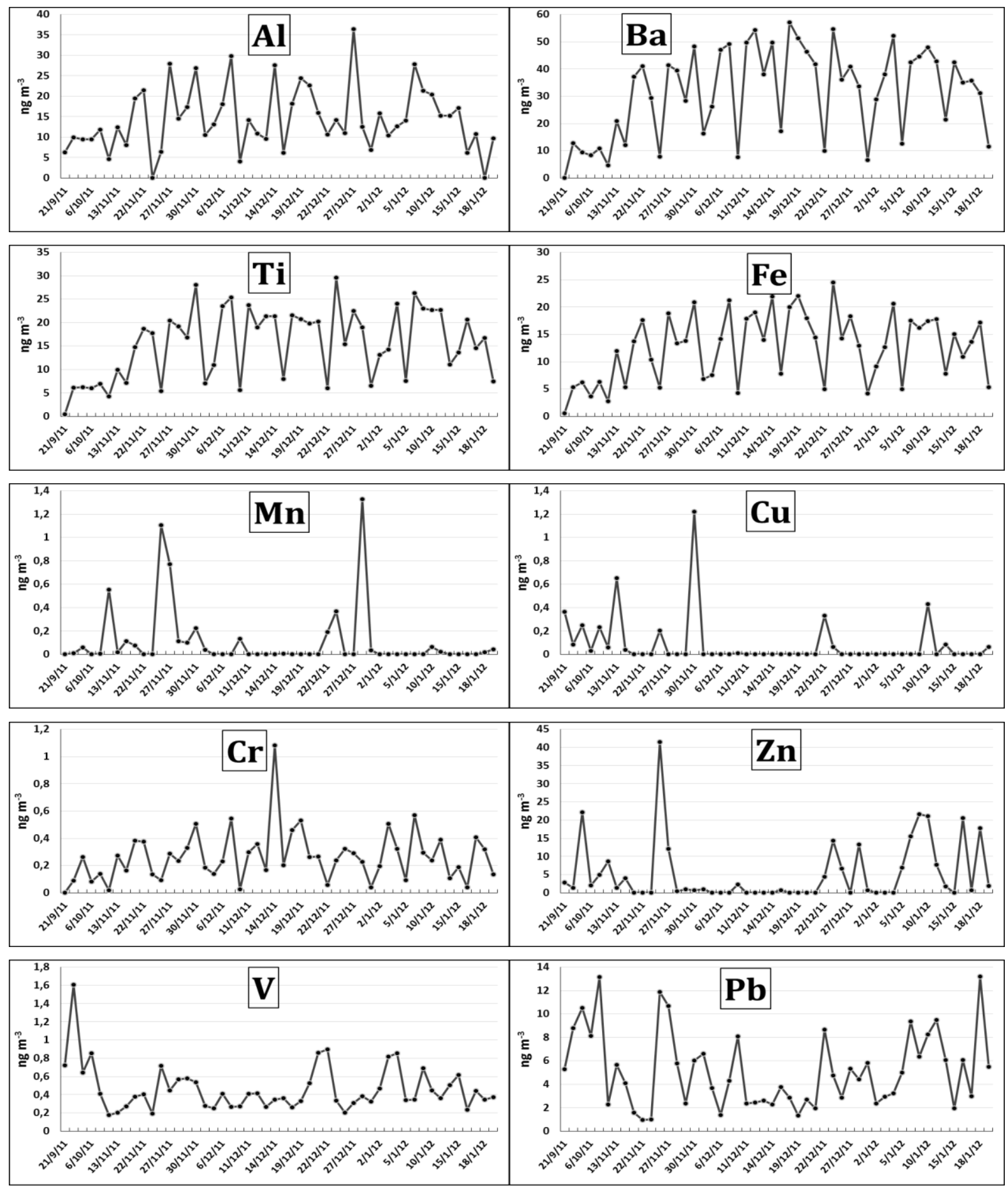

Fig. 4. Concentration time series of the main metal elements measured at Bou Ismail (2011-2012).

in the present study by the daily variations of the arabitol and levoglucosan levels, which confirm that emissions of these compounds originate in different sources.

The levoglucosan and arabitol concentration levels in the aerosol samples ranged from 3.8 to $211 \mathrm{ng} \mathrm{m}^{-3}$ and 0.09 to $20.6 \mathrm{ng} \mathrm{m}^{-3}$, respectively. The concentrations of both sugars were about two times higher in winter than in fall. Notably, there were three extreme days observed for levoglucosan: January 10, $2012\left(211 \mathrm{ng} \mathrm{m}^{-3}\right)$, January 8, $2012\left(165 \mathrm{ng} \mathrm{m}^{-3}\right)$, and January 11, $2012\left(143 \mathrm{ng} \mathrm{m}^{-3}\right)$. Arabitol concentrations also peaked on two days: November 24, 2011 (20.6 $\mathrm{ng} \mathrm{m}^{-3}$ ) and December 28, 2011 (19 $\left.\mathrm{ng} \mathrm{m}^{-3}\right)$, which could be explained by the presence of primary biological aerosols in our samples during those days.

The high levoglucosan values in the Bou Ismail coastal region in the winter might have occurred due to bonfires on the beach, wood that was used for heating, and the burning of fallen leaves in the fall. 


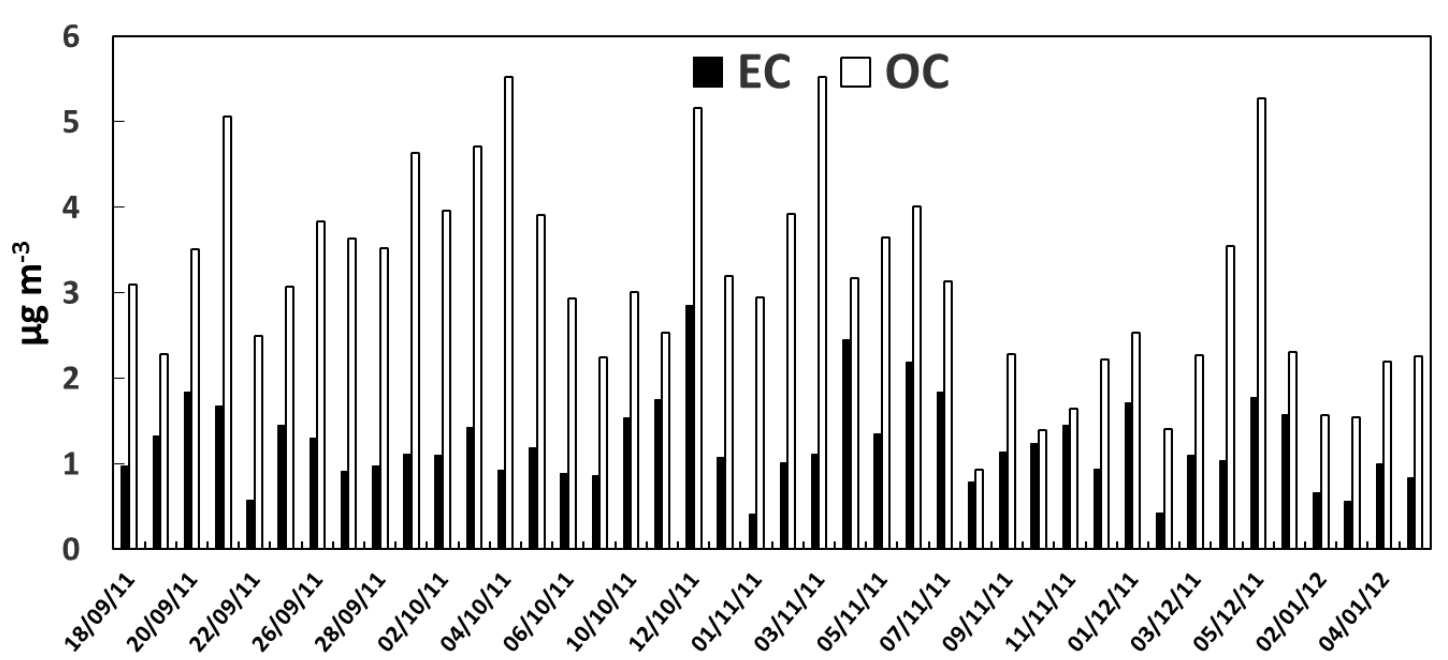

Fig. 5. Concentration time series of carbonaceous material (EC/OC) measured at Bou Ismail (2011-2012).

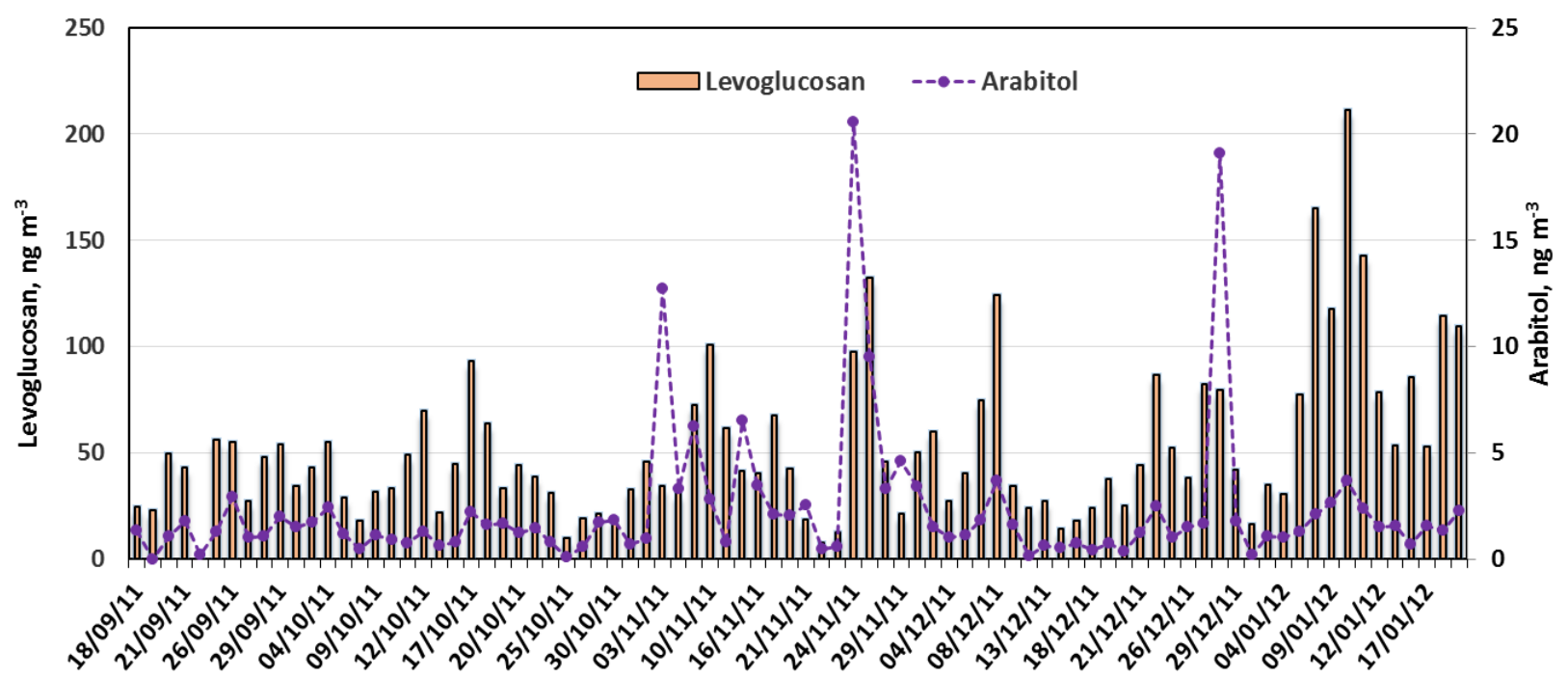

Fig. 6. Concentration time series of the anhydrosaccharide levoglucosan and the saccharide alcohol arabitol measured at Bou Ismaïl (2011-2012).

The large variations observed in winter could be attributed to the spatial inhomogeneity of biomass burning and various types of air masses (marine and dust) that come to the north of Algiers in Bou Ismaïl. Additionally, temperature, wind conditions, and the type and number of fires might also have played an important role in levoglucosan levels (Reche et al., 2012; Scaramboni et al., 2015).

The concentration levels of levoglucosan recorded in this study were compared to measured values from other locations of the Mediterranean (see Table 2). In Bou Ismail, levoglucosan fell in the same range as the semi-urban areas of Beirut, Lebanon (Waked et al., 2014), although they were higher than in Finakolia, Greece (Li et al., 2013).

\section{Dicarboxylic Acids (DCA)}

Fig. 7 shows the concentrations of five dicarboxylic acids that were measured in the marine aerosol of Bou Ismaill.

Systematically, oxalate is the most abundant of these species, with concentrations between 31 and $432 \mathrm{ng} \mathrm{m}^{-3}$, followed by malonate $\left(1.72-81.5 \mathrm{ng} \mathrm{m}^{-3}\right)$ and succinate $(0.36-70.5)$, whose concentrations are very close to each other. However, no malate was detected throughout the first two months (September and October) and only the observed average concentration of other periods are presented in this study.

The concentrations and maximum values of oxalate were generally higher in fall (September and October) than in winter (November-January). This can be explained by the dominance of secondary sources during the warm season (fall) compared to the cold season (winter). On average, malonate and succinate did not show apparent seasonal variations, but were slightly higher in winter than fall. Glutarate was measured with similar concentrations in both seasons although its fall concentrations were slightly higher. Contrary to this, concentrations of malate do not allow for a more in-depth comparison because it was only detected in three winter months.

The secondary production of oxalate is probably induced by precursors, especially through the photo-oxidation of 


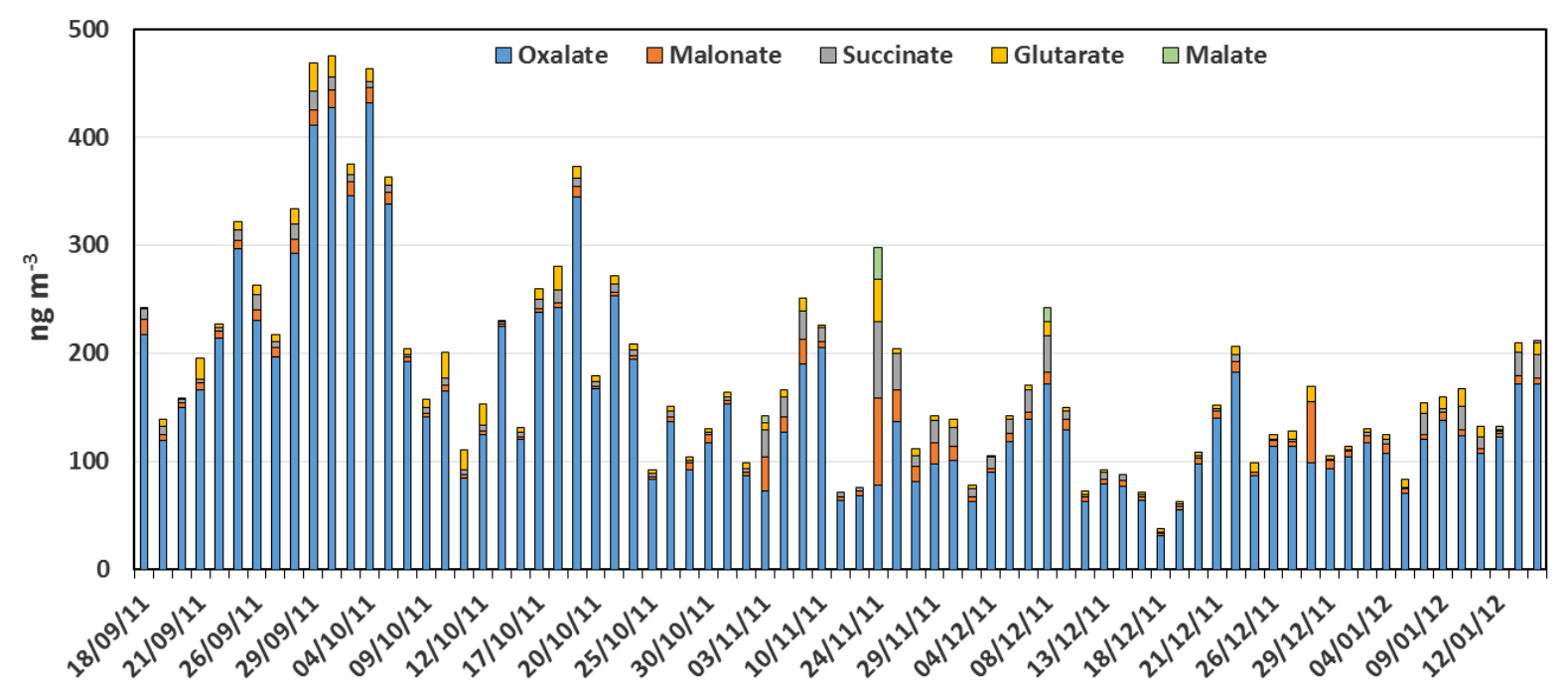

Fig. 7. Concentration time series of the five dicarboxylic acids (DCAs) that were measured in the marine aerosol of Bou Ismaïl (2011-2012).

hydrocarbons and other diacids, such as malonic or succinic acid (Kawamura and Gagosian, 1987; Ebert et al., 2000; van Pinxteren et al., 2014). The concentrations of the other acids do not allow for a more in-depth comparison between the different periods studied here. The mean concentrations of the oxalate recorded in the coastal region of Bou Ismaïl were compared with those from earlier studies in the Mediterranean Sea (see Table 2). The oxalate concentration levels are higher than those recorded in the atmosphere of Tetouan, Morocco (Benchrif et al., 2018), as well as in semi-urban Beirut, Lebanon (Waked et al., 2014). They are of the same order of magnitude as those recorded on the mountain Aitana in Spain (Galindo et al., 2017), but they are lower than those in Oporto in Portugal (Custódio et al., 2016) and Salento in Italy (Pietrogrande et al., 2018).

\section{Semi-volatile Organic Compounds (SVOCs)}

Fig. 8 presents the average cumulative concentrations of each group of semi-volatile organic compounds (SVOCs) recorded over the course of five months. The total yields (the sum of all identified organics) observed in the Bou Ismail region are also given.

The average total $n$-alkane concentrations during the five months were determined to be at $38.3 \mathrm{ng} \mathrm{m}^{-3}$ (September), $29.9 \mathrm{ng} \mathrm{m}^{-3}$ (October), $20.1 \mathrm{ng} \mathrm{m}^{-3}$ (November), $19.5 \mathrm{ng} \mathrm{m}^{-3}$ (December), and $30.9 \mathrm{ng} \mathrm{m}^{-3}$ (January). The n-alkane concentrations peaked at $\mathrm{C}_{25}-\mathrm{C}_{29}$, with $\mathrm{C}_{25}$ and $\mathrm{C}_{31}$ as predominant congeners, while the n-alkane concentrations up to $\mathrm{C}_{23}$ were much lower. The highest levels were reached by $\mathrm{C}_{31}$ in September $\left(5.14 \mathrm{ng} \mathrm{m}^{-3}\right)$ and October $\left(4.21 \mathrm{ng} \mathrm{m}^{-3}\right)$, while in the months of November, December, and January, the predominant compounds were $\mathrm{C}_{25}, \mathrm{C}_{26}$, and $\mathrm{C}_{27} . \mathrm{C}_{\max }$ $\left(\mathrm{C}_{29}, \mathrm{C}_{31}\right)$ imply strong biogenic input, whilst the lower rates ( $\approx 1$ and $\mathrm{C}_{19}$ up to $\mathrm{C}_{25}$, respectively) are typical of anthropogenic sources (Pio et al., 2001). As can be seen in Fig. 9, the concentrations of n-alkanes in the warm times were slightly higher than in the cold ones.

Additionally, pristane (26-, 10-, 14- tetramethylpentadecane) and phytane (2-, 6-, 10-, 14-tetramethylhexadecane) were identified and quantified as molecular markers of vehicular emissions; average values of pristane ranged from 0.02 to $0.96 \mathrm{ng} \mathrm{m}^{-3}$, while those of phytane varied between 0.09 and $1.04 \mathrm{ng} \mathrm{m}^{-3}$.

Twenty-two PAHs with 3 to 7 rings were identified and quantified. Fluorene (FA), benzo(ghi)perylene, and retene were the most abundant of them in aerosol particles and contributed approximately $56 \%$ of the total PAH concentrations.

The predominant low molecular weight congener FA and high molecular weight congener BghiP characterize coarse and fine particles, respectively (Ladji et al., 2014).

The predominance of fluorene (FA) can be explained by the fact that its concentrations in the air were to some degree underestimated because of the high volatility of the PAHs with two to four aromatic rings, which led to them accumulating under ambient conditions in the gas phase rather than the particulate phase (Khedidji et al., 2013).

Moreover, it was determined that retene has higher levels in winter $\left(1.48 \mathrm{ng} \mathrm{m}^{-3}\right)$ than fall $\left(0.74 \mathrm{ng} \mathrm{m}^{-3}\right)$. Retene is a marker compound for coniferous wood combustion (Spindler et al., 2012). This compound's presence in the marine environment is assumed to arise out of local emissions by burning wood/coal in individual stoves during the cold season. This is a strong indication for the long-range transport of anthropogenic air masses.

Additionally, the hypothesis of lignite combustion sources can be excluded from the present study due to the absence or low quantity of benzonaphthol $(1,2-d)$ thiophene in our samples ( 0.001 to $0.07 \mathrm{ng} \mathrm{m}^{-3}$ ).

Contrary to what has been observed for alkanes, the PAH concentrations determined during the winter months are more important than those during the fall ones. This seems to match the general evolution of the meteorology dominating the Bou Ismail region, although the combustion processes are the main sources of these compounds (Khedidji et al., 2017; Rabhi et al., 2018). Indeed, the inversion of temperature 


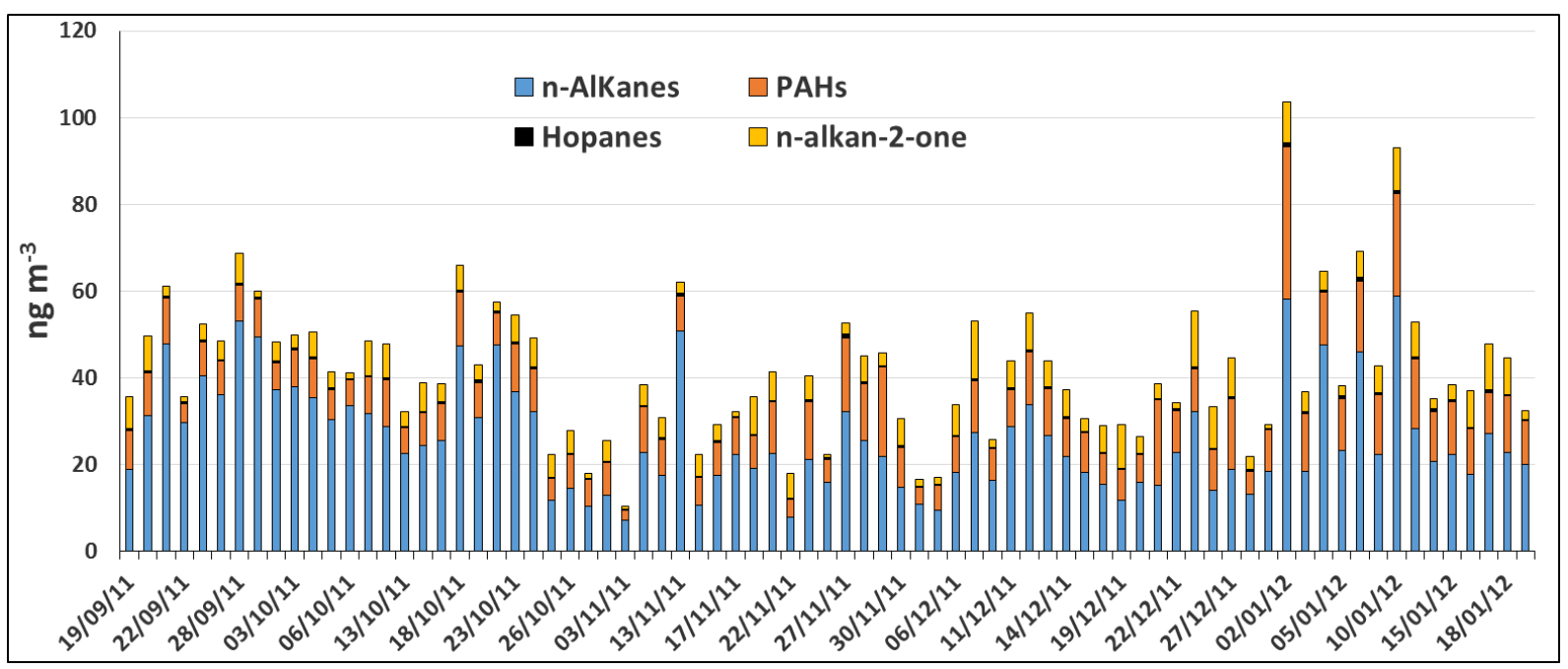

Fig. 8. Concentration time series of cumulative concentrations of n-alkanes, hopanes, alkan-2 one, PAHs, and their derivatives.
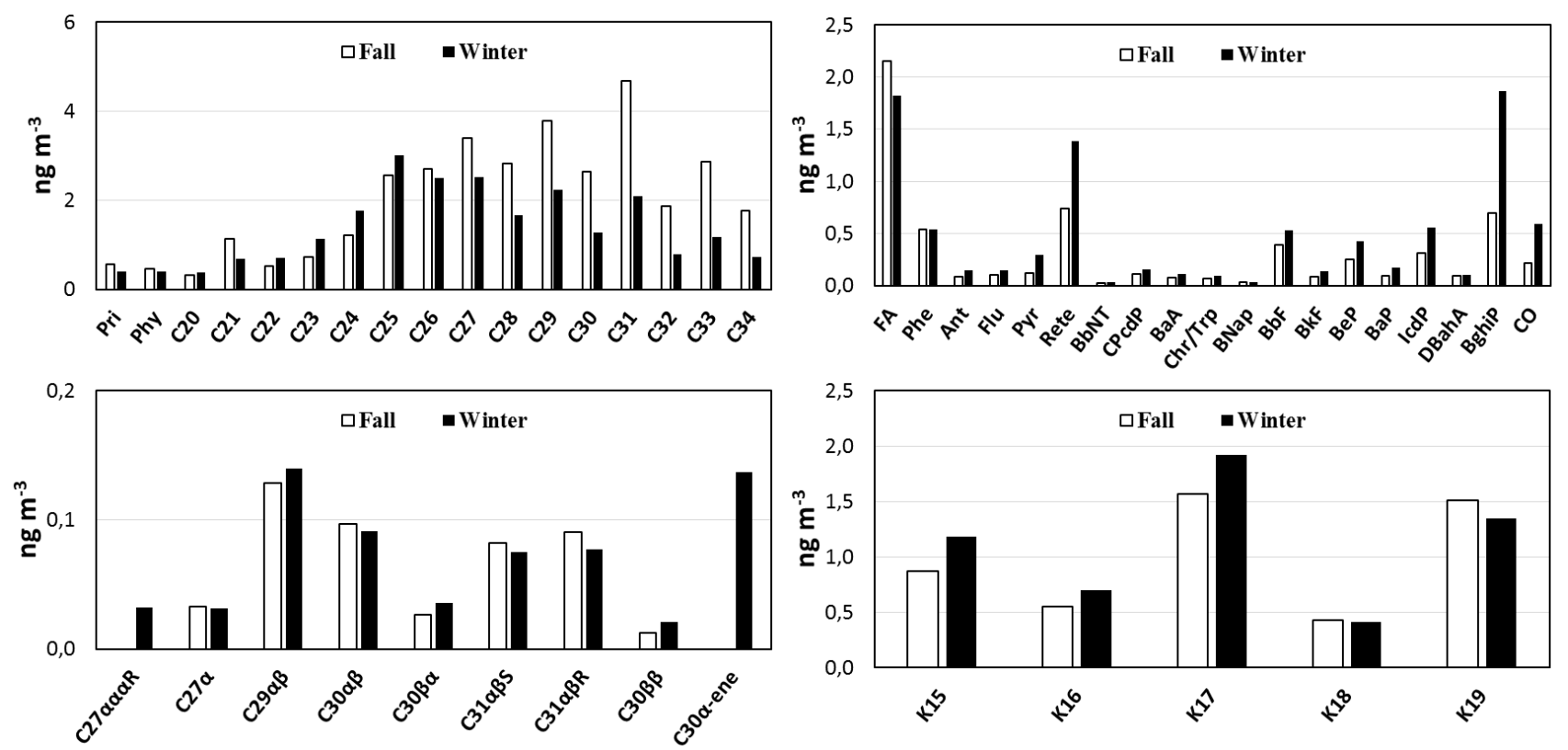

Fig. 9. Seasonal evolution of n-alkanes, hopanes, alkan-2-one, PAHs, and their derivatives.

in the lower troposphere is very frequent in winter and prevents the dispersion of the PAHs so that they accumulate above the earth's surface layer, while low ambient temperatures shift the partition of semi-volatile species toward the condensed phase (Ladji et al., 2009a). Nevertheless, the concentration levels of PAHs determined in the different periods of the campaigns are lower than those of alkanes.

In the present study, we focused our attention on oxygenated PAHs such as 9H-fluoren-9-one, 9,10-anthracenedione, and benzanthracene-7,12-dione. 9H-fluoren-9-one was always the most abundant oxygenated PAHs and ranged from 0.27 to $1.21 \mathrm{ng} \mathrm{m}^{-3}$.

A series of hopanes was detected in the marine samples, with total concentrations ranging from $0.14 \mathrm{ng} \mathrm{m}^{-3}$ in
November to $1 \mathrm{ng} \mathrm{m}^{-3}$ in January. The concentrations of the compounds that were measured in the winter were slightly higher than the ones in the fall.

The molecular composition of hopanes is characterized by two major congeners at $17 \alpha(\mathrm{H}), 21 \beta(\mathrm{H})$-Norhopane $(\mathrm{C} 29 \alpha \beta)$ and $17 \alpha(\mathrm{H}), 21 \beta(\mathrm{H})-30$-hopane $(\mathrm{C} 30 \alpha \beta)$ in both seasons, while Hop-17(21)-ene (C30 $\alpha$-ene) and $\alpha, \alpha, \alpha 20 \mathrm{R}-$ Cholestane $(\mathrm{C} 27 \alpha \alpha \alpha \mathrm{R})$ only occur in winter. However, the distributions of the hopane series derived from the other period were very similar. This suggests that the emission characteristics of hopanes might be independent of temporal variation. Hopanes can decompose by reacting with $\mathrm{OH}$ radicals in the atmosphere, and tend to quickly disappear, leaving space for their oxidation byproducts (Fu et al., 2010). 
Hopanes are known as petroleum molecular markers and are specific indicator compounds mainly present in hydrocarbon fractions. They can be used to trace the contributions of motor vehicle exhausts to airborne PM (El Haddad et al., 2009).

The concentrations of these compounds and their relative distributions in the atmosphere depend on their emission sources. Therefore, in direct vehicular emissions, the majority of hopanes are $17 \alpha(\mathrm{H}), 21 \beta(\mathrm{H})$-Norhopane $(\mathrm{C} 29 \alpha \beta)$ and $17 \alpha(\mathrm{H}), 21 \beta(\mathrm{H})$-Hopane $(\mathrm{C} 30 \alpha \beta)$, while in coal stove emissions, the majority of the compounds are $17 \alpha(\mathrm{H})$ 22,29,30-Trisnorhopane (C27 $)$ (El Haddad et al., 2009).

The $(\mathrm{C} 29 \alpha \beta / \mathrm{C} 30 \alpha \beta)$ ratio documented values of 2.5 for diesel emissions, 3.7 for gasoline engines, and 0.1 to 2.6 for coal combustion (Oros and Simoneit, 2000). In our case, the average ratio ranged from 1.19 to 1.61 , suggesting a fingerprint of coal emissions. However, the predominance of $\alpha \beta$-configuration compounds on the marine site indicates that a petroleum derivative of high maturity is used on this site.

The total content of n-alkane-2-one was between 0.67 to $13.24 \mathrm{ng} \mathrm{m}^{-3}$ and peaked in December. The same pattern of distribution of n-alkan-2-one concentrations was observed in both seasons, suggesting that they come from similar sources. However, the n-alkan-2-one levels were much lower than those of n-alkanes.

Furthermore, two main sources are known to be responsible for the presence of $n$-alkane-2-one in the air: incomplete combustion and in-situ microbial $\alpha$-oxidation of the carbon chain (Yassaa et al., 2001a). The first source often creates n-alkane-2-one with a predominance of oddnumbered carbon atoms; on the other hand, the last source gives rise to the opposite.

In the present study, a strong predominance of odd nalkane-2-one rather than pairs was clearly observed for these compounds, suggesting that the incomplete combustion of organic material was the principal ambient source in this region. In particular, heptadecane-2-one (K17) was the most abundant in all the samples and reached a maximum $5.23 \mathrm{ng} \mathrm{m}^{-3}$.

The total contents of n-alkanes, PAHs and n-alkan-2-ones were compared to $\mathrm{PM}_{10}$ contents measured in other locations of Algeria and the world.

The levels of n-alkanes in this study were clearly lower compared to those reported in other Algerian cities such as in industrial district (Yassaa and Cecinato, 2005; Khedidji et al., 2017) and in urban areas (Ladji et al., 2009a; Ladji et al., 2014), although they were higher than recorded in the marine atmosphere of southern and eastern Mediterranean Sea by Romagnoli et al. (2016).

Total PAHs were lower than those reached in the industrial area of Hassi-Messaoud (22-65 $\left.\mathrm{ng} \mathrm{m}^{-3}\right)$, in an urban environment in southwest China $\left(79.6 \mathrm{ng} \mathrm{m}^{-3}\right)$ and at residential sites in Taiwan $\left(45.2-44.1 \mathrm{ng} \mathrm{m}^{-3}\right.$ ) (Yassaa and Cecinato, 2005; Hi et al., 2019; Zhu et al., 2019). However, they were similar to those recorded in industrial areas (6-11 $\mathrm{ng} \mathrm{\textrm {m } ^ { - 3 }}$ ), in urban ambient air of Tafourah $\left(15.9 \mathrm{ng} \mathrm{m}^{-3}\right)$ and in the urban zone of Ben Aknoun (13-16 $\mathrm{ng} \mathrm{m}^{-3}$ ) (Ladji et al., 2009a; Ladji et al., 2014; Khedidji et al., 2017), but were much higher compared to those reported for Italian locations such as in the coastal area (Romagnoli et al., 2016) and Naples (Di Vaio et al., 2016).

Generally, the concentrations of n-alkan-2-ones appear to be very low when compared to those usually reported for industrial processes in Algiers $\left(121 \mathrm{ng} \mathrm{m}^{-3}\right.$ ) (Yassaa et al., 2001a), the industrial area of Hassi-Messaoud (27.8 $\mathrm{ng} \mathrm{m}^{-3}$ ), and Oued Smar (32.07 $\mathrm{ng} \mathrm{m}^{-3}$ ) (Yassaa et al., 2001b; Yassaa and Cecinato, 2005).

\section{ASSESSMENT OF AEROSOL SOURCES}

\section{Spearman Rank Correlation}

In order to determine the nature, strength, and relevance of the correlations between variables, a spearman rank correlation analysis was performed (Table 3). The total contents of PAHs, alkanes, hopanes, and alkanones were used for statistical calculations, while for the ions their individual concentrations were used.

The two main sources of chloride in atmospheric aerosols are emissions from sea salt that are mainly associated with sodium (Quinn, 2004; Kumar et al., 2008; Zhao and Gao, 2008) and its outcome from coal combustion (Zhao and Gao, 2008), whereas sodium originates in sea spray. $\mathrm{Ca}^{2+}$ and $\mathrm{Mg}^{2+}$ mainly originate in crustal sources and can also have marine origins. A high positive correlation coefficient was found between $\mathrm{Na}^{+}, \mathrm{Cl}^{-}, \mathrm{Ca}^{2+}$, and $\mathrm{Mg}^{2+}$ on the one hand and a negative correlation of these ions with $\mathrm{OC}$ on the other hand. This indicates that these four ions have a common source, which could be attributed to the sea salt that is a principal part of marine sources in this area.

A Spearman rank order correlation matrix indicates a strong correlation of oxalate with $\mathrm{K}^{+}, \mathrm{SO}_{4}{ }^{2-}$, and $\mathrm{NH}_{4}{ }^{+}(\mathrm{rho}=$ 0.676 , rho $=0.839$, and rho $=0.784$, respectively; Table 3 ), which suggests that biomass burning emissions (Hays et al., 2005; Tang et al., 2014) and secondary transformations are important sources of shorter-chain di-acids. Moreover, the high correlation coefficient between $\mathrm{NH}_{4}{ }^{+}$and $\mathrm{SO}_{4}{ }^{2-}$ (rho $=$ 0.87 ) and the slightly lower one between $\mathrm{NH}_{4}{ }^{+}$and $\mathrm{NO}_{3}{ }^{-}$ $($ rho $=0.414)$ can suggest that $\left(\mathrm{NH}_{4}\right)_{2} \mathrm{SO}_{4}$ and $\left(\mathrm{NH}_{4} \mathrm{NO}_{3}\right)$ are the major ionic species in $\mathrm{PM}_{10}$.

The conversion of gaseous $\mathrm{NH}_{3}$ to particulate $\mathrm{NH}_{4}{ }^{+}$depends on the concentration of acids in the atmosphere, temperature, and water availability, as well as the flux rates of $\mathrm{NH}_{3}$. Strong correlation between $\mathrm{SO}_{4}{ }^{2-}$ and $\mathrm{NH}_{4}{ }^{+}$as described bellow indicated that ammonium was present as ammonium sulfate $\left(\left(\mathrm{NH}_{4}\right)_{2} \mathrm{SO}_{4}\right)$. Whereas $\left(\mathrm{NH}_{4} \mathrm{NO}_{3}\right)$ is a product of gas-phase reactions between ammonia and nitric acid (Meng et al., 2016).

The strong correlation coefficients of rho $=0.699$ for $\mathrm{NO}_{3}{ }^{-}-\mathrm{Cl}^{-}$, rho $=0.65$ for $\mathrm{NO}_{3}{ }^{-}-\mathrm{Na}^{+}$, rho $=0.68$ for $\mathrm{NO}_{3}{ }^{-}-$ $\mathrm{Mg}^{2+}$, and rho $=0.714$ for $\mathrm{NO}_{3}{ }^{-}-\mathrm{Ca}^{2+}$ indicate that the major source of nitrate ions in $\mathrm{PM}_{10}$ samples was the reaction of precursor gases $\left(\mathrm{HNO}_{3}\right)$ with marine species through heterogeneous condensation (Li et al., 2014).

Moreover, a highly significant correlation between the organic compounds, namely alkanes, PAHs, hopanes, and alkan-2-ones, indicates that these pollutants have common sources, which could be attributed to traffic and to related industrial activity in this area (Khedidji et al., 2017). 


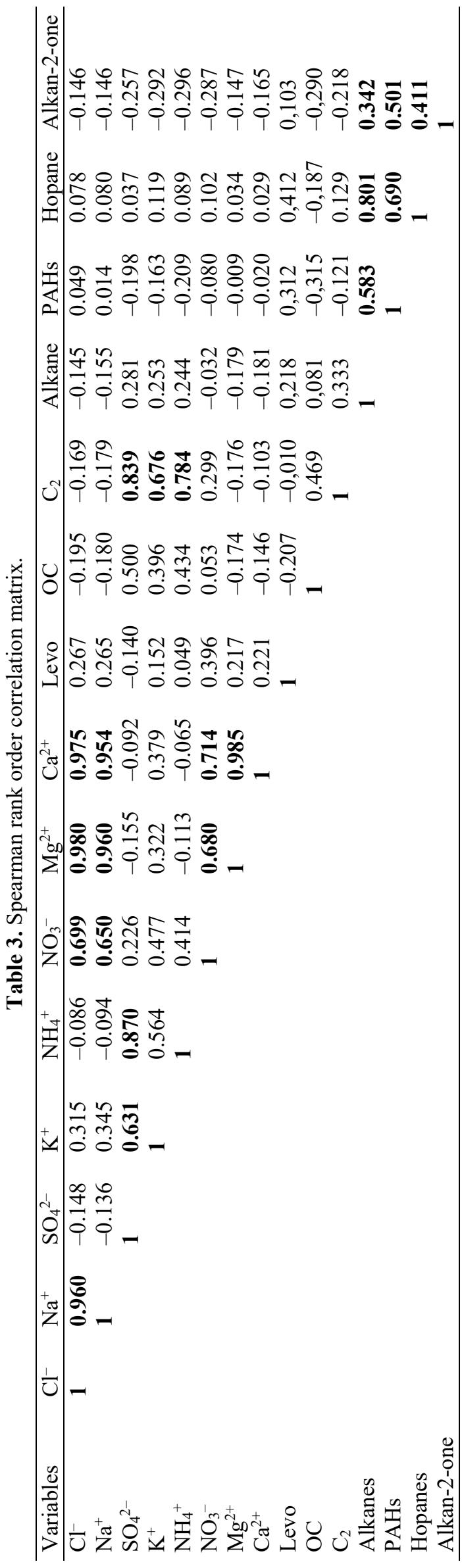

The sources proposed through the Spearman rank correlation will be further discussed in the next section by analyzing molecular fingerprints and diagnostic ratios.

\section{Non-sea-salt Sulfate Contributions}

Non-sea-salt sulfate (nss- $\mathrm{SO}_{4}{ }^{2-}$ ) is calculated from sodium under the assumption that $\mathrm{Na}^{+}$is of a marine origin only (Seinfeld and Pandis, 1998). The calculation goes as follows:

nss- $\mathrm{SO}_{4}{ }^{2-}=\mathrm{SO}_{4}{ }^{2-}$ Total $-\left(\left[\mathrm{SO}_{4}{ }^{2-} / \mathrm{Na}^{+}\right]_{\text {marine }} \times \mathrm{Na}^{+}\right.$Total $)$

with $\left[\mathrm{SO}_{4}{ }^{2-} / \mathrm{Na}^{+}\right]_{\text {marine }}=0.25$ (Morales et al., 1998; Zhou et al., 2016).

The values of nss- $\mathrm{SO}_{4}{ }^{2-}$ ranged in a similar way, regardless of the sampling time (Table 4). They are comparable to those observed on other European sites with different topologies (Putaud et al., 2004). During this study, mass fractions of non-sea-salt sulfate (nss-SO ${ }_{4}{ }^{2-}$ ) to total sulfate varied between 76 and $98 \%$, which confirms the anthropogenic nature of the source of sulfate. This finding is further confirmed by the Spearman rank analysis resulting in correlation between sulfate and potassium of rho $=0.631$.

\section{EC and OC Sources: Tracer of Primary and Secondary \\ Emissions}

A simple expression has been adopted to differentiate between primary OC (OCpri) and secondary OC (OCsec) from concentrations of EC and total OC (OCtot) (Spindler et al., 2012).

$\mathrm{OC}_{\mathrm{Pri}}=(\mathrm{EC}) \times(\mathrm{OC} / \mathrm{EC})_{\min }$

$\mathrm{OC}_{\mathrm{Sec}}=(\mathrm{OC})_{\mathrm{tot}}-(\mathrm{OC})_{\mathrm{Pri}}$

In the current study, the average value of primary OC (OCpri) was at $1.77 \mu \mathrm{g} \mathrm{m}^{-3}$ and ranged from 0.47 to 4.13 $\mu \mathrm{g} \mathrm{m}^{-3}$, while secondary OC (OCsec) was estimated to be at $2.64 \mu \mathrm{g} \mathrm{m}^{-3}$ and ranged from 0.84 to $5.39 \mu \mathrm{g} \mathrm{m}^{-3}$ (Fig. 10).

The secondary organic carbon (OCsec) was consistently higher than the primary organic carbon (OCpri). Therefore, the formation of secondary organic aerosols (SOA) from biogenic or anthropogenic precursors appears to be strong in the Bou Ismaill region.

A different approach was chosen to separate primary OC from combustion and other sources (non-combustion) (Russell and Allen, 2004). The method determines the minimum slope of the regression line between the concentrations of the total OC and those of EC. The OC/EC slope corresponds to the primary sources of combustion, while the interception gives information about the contribution of primary sources other than combustion.

Fig. 11 shows the correlation between $\mathrm{OC}$ and $\mathrm{EC}$ in different measurement periods. Since these correlations are based on only few data points, their values are mainly used to indicate possible trends during the five months.

The correlation is strong in January $\left(\mathrm{R}^{2}=0.59\right)$ and significantly lower in November $\left(\mathrm{R}^{2}=0.05\right)$. Additionally, the regression slopes in the months of September, October, and November are much lower than the ones recorded in 
Table 4. Monthly values of non-sea salt measured at Bou Ismail (in $\mu \mathrm{g} \mathrm{m}^{-3}$ and \%).

\begin{tabular}{|c|c|c|c|c|c|c|}
\hline Months & September & October & November & December & January & Mean \\
\hline $\mathrm{SO}_{4}{ }^{2-}\left(\mu \mathrm{g} \mathrm{m}^{-3}\right)$ & 2.44 & 1.82 & 0.85 & 0.74 & 0.91 & 1.35 \\
\hline 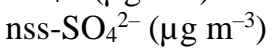 & 2.39 & 1.75 & 0.64 & 0.63 & 0.81 & 1.25 \\
\hline nss-SO ${ }^{2-}(\%)$ & 98.02 & 96.36 & 75.78 & 85.76 & 89.43 & 92.29 \\
\hline
\end{tabular}

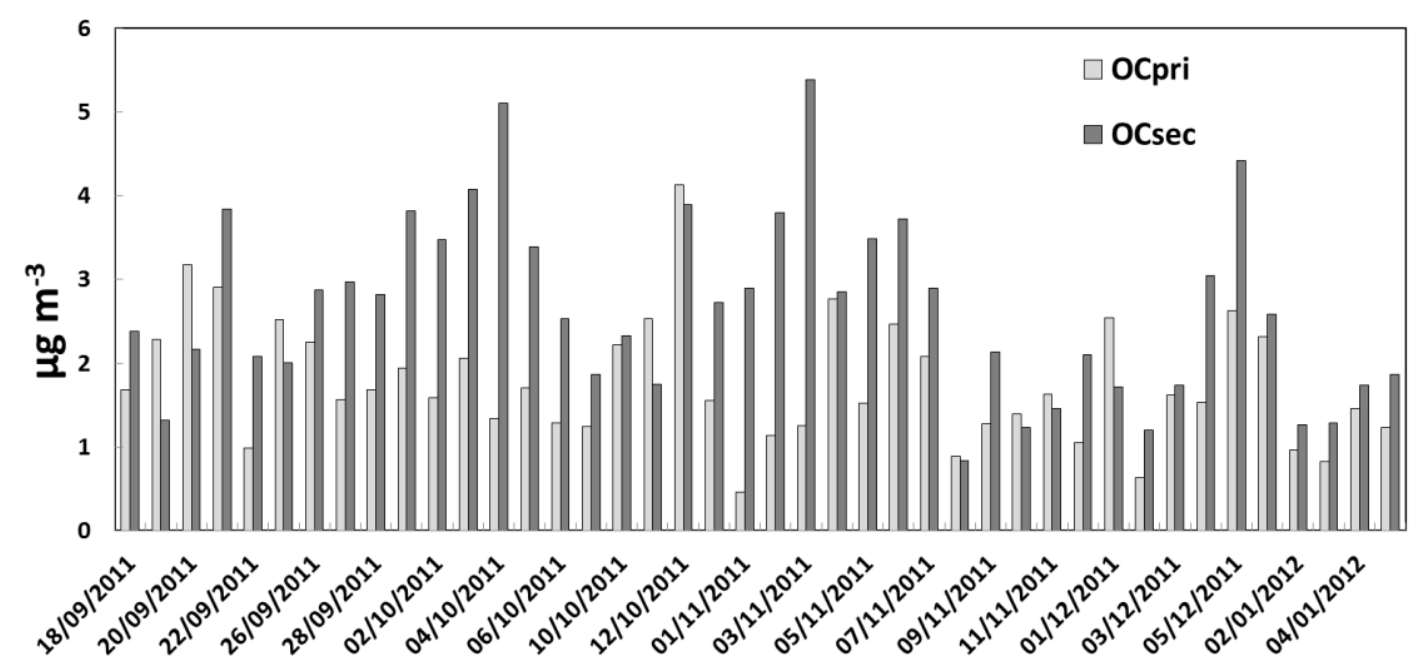

Fig. 10. Daily assessment of primary organic carbon (OCpri) and secondary organic carbon (OCsec) measured at Bou Ismaill.
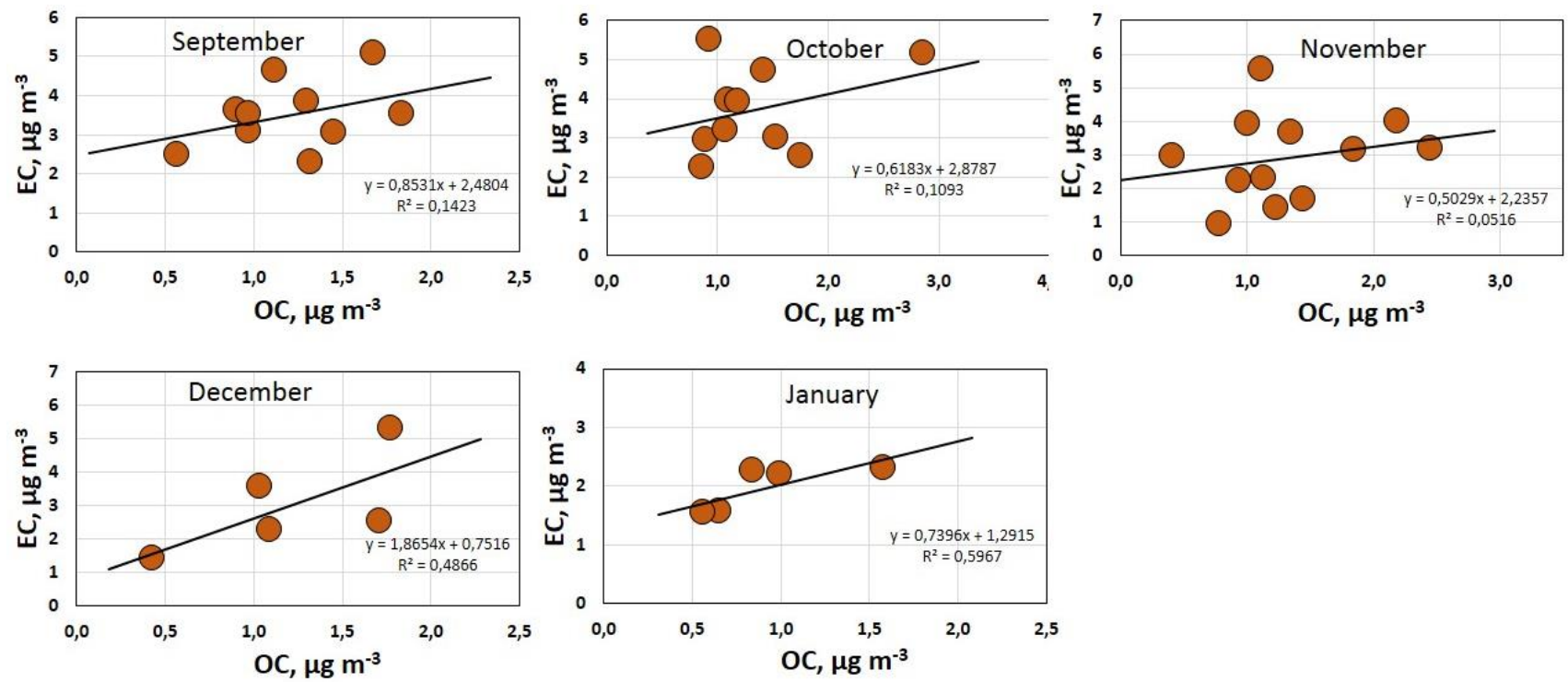

Fig. 11. Correlations between EC and OC concentrations during the five months.

December and January. Consequently, the strong correlation observed in January seems to indicate a great homogeneity in the nature of the sources of carbonaceous material in this month. The slopes observed in September, October, and November are lower, indicating a greater distance from the sources of carbonaceous matter (i.e., less primary aerosol) and/or sources with different profiles than in the other months.

The lower correlation in November indicates a high variability of the sources. This is quite compatible with the diversity of air mass sources in late winter and early fall (November) and also matches the general observations of the primary and secondary organic carbon values (see previous section). The intercepts are lower in December and January, most likely indicating a lower impact of OC sources that do not produce EC.

\section{SOURCES OF ORGANIC AEROSOLS}

In the present study, different diagnostic parameters were adopted to explore natural and anthropogenic contributions to the observed concentrations of organic particle constituents, comprising Carbon preference indexes (CPI), contributions 
of natural wax n-alkanes $\left(\mathrm{C}_{\mathrm{WAX}}\right)$ and petrogenic n-alkanes $\left(\mathrm{C}_{\mathrm{PTR}}\right)$, and molecular diagnostic ratios (DRs) of PAHs (Yassaa et al., 2001a; Ladji et al., 2009b; Cecinato et al., 2014).

\section{Anthropogenic and Biogenic Sources}

In order to better understand the natural sources of n-alkanes from the epicuticular waxes of plants and anthropogenic sources originating in fossil fuel, a carbon preference index (CPI) computation was applied. A CPI rate was calculated by the following formula:

$$
\mathrm{CPI}=\sum\left(\mathrm{C}_{21}-\mathrm{C}_{33}\right) / \sum\left(\mathrm{C}_{20}-\mathrm{C}_{32}\right)
$$

It is well known that n-alkanes originate in epicuticular waxes of plants and exhibit higher values of CPI (CPI >>1) than vehicle emissions and other anthropogenic activities, which are characterized by CPI values close to 1 (Kavouras, 2002).

As can be seen in Table 5, the CPI values increased to around 1.5 in the marine samples in both seasons and always decreased in the range of 1.39 to 1.64 , suggesting a mixed situation where the emissions were dominated by petroleum-related sources but a slight influence by high plant waxes survived.

The contribution of these waxes $\left(\mathrm{C}_{\mathrm{WAX}}\right)$ to the total amount of n-alkanes $\left(\mathrm{C}_{\text {TOT }}\right)$ can be quantified using Eq. (5). The remaining $\mathrm{n}$-alkanes are assumed to come from petroleum sources (C $\mathrm{C}_{\mathrm{PTR}}$ ) (Simoneit et al., 1991; Pio et al., 2001; Yue and Fraser, 2004). Overall, the predominance of n-nonacosane $\left(\mathrm{C}_{29}\right)$ and hentriacontane $\left(\mathrm{C}_{31}\right)$ (typically associated with higher plant waxes) among high molecular weight homologues was indicative of a mixed impact of natural sources (Khedidji et al., 2017).

The wax-negative $\mathrm{Cn}$ values are considered null values. Consequently, only n-alkanes with an odd number of carbon contribute to vegetable waxes (Simoneit, 1984; Li et al., 2010).

$$
C_{W A X}=\sum_{n=20}^{n=33}\left(C_{n}-\frac{C_{n-1}+C_{n+1}}{2}\right)
$$

Biogenic n-alkane contribution $\left(\mathrm{C}_{\mathrm{WAX}}\right)$ makes up between $12 \%$, and $31.65 \%$, with $n$-hentriacontane and n-nonacosane being the principal homologues associated with vegetation, accounting for ca. $5.57 \%$ and $3.16 \%$ of all total plant wax n-alkanes, respectively (see fig. 12).

This suggests the existence of a mixed situation, in which emissions are dominated by anthropogenic sources, with a modest contribution by alkanes derived from vegetable waxes.

\section{Diagnostic Ratios (DRs): Vehicular Emissions, Wood Burning, and Coal Combustion Contributions}

In order to determine the major sources of these pollutants during the five months studied, the ratios between the PAH concentrations were calculated (Khedidji et al., 2013; Balducci et al., 2014; Cecinato et al., 2014). Some criticism has been directed at this technique since PAH data and DRs do not tend to vary systematically with respect to atmospheric conditions and often seem to be unrelated to particular sources (Marchand et al., 2004). However, qualitative information remains inferable when three or more $\mathrm{PAH}$ ratios are considered.

The reports of [BghiP/BeP], [CHAP/THAP], [Phe/(Phe + Ant $)],[\mathrm{IcdP} /(\mathrm{IcdP}+\mathrm{BghiP})],[\mathrm{Flu} /(\mathrm{Flu}+\mathrm{Pyr})]$, and $[\mathrm{BaP} /(\mathrm{BaP}$ $+\mathrm{BeP})]$ are graphically illustrated in Fig. 13.

For instance, [CHAP/THAP] rates close to $0.3,0.41$, and 0.51 were calculated for heavy-duty diesel trucks, non-catalyst automobiles, and catalyst-equipped automobiles, respectively (He et al., 2010). In our samples, the [CHAP/THAP] ratio values obtained throughout the whole period were comparable to those of heavy-duty diesel trucks, except for the month of January. This is confirmed by the [BghiP/BeP] report, which characterizes vehicular emissions in four months and their absence in January. Analogous results were drawn by analyzing the $[\mathrm{Phe} /(\mathrm{Phe}+\mathrm{Ant})]$ ratio; in this regard, values $\geq 0.7$ are typically associated with lubricant oils and fossil fuels, and those $\leq 0.7$ with solid fuel exhausts (Vicente et al., 2012). The [Phe/(Phe + Ant)] ratio shows that these PAHs are essentially issued forth by burning fossil

Table 5. Diagnostic parameters applied to concentrations of organic compounds.

\begin{tabular}{llllll}
\hline Diagnostic parameters & September & October & November & December & January \\
\hline CPI n-alkanes & $1.54 \pm 0.07$ & $1.64 \pm 0.18$ & $1.39 \pm 0.17$ & $1.44 \pm 0.15$ & $1.46 \pm 0.17$ \\
Cwax & $6.58 \pm 1.91$ & $6.44 \pm 3.04$ & $3.22 \pm 2.41$ & $3.15 \pm 1.05$ & $5.03 \pm 2.32$ \\
Cwax n-alkanes $(\%)$ & 17.41 & 20.79 & 15.34 & 16.70 & 17.18 \\
Cptr & $31.73 \pm 10.08$ & $23.49 \pm 7.92$ & $16.91 \pm 8$ & $16.31 \pm 6.33$ & $25.92 \pm 13.15$ \\
Cptr n-alkanes (\%) & 82.59 & 79.21 & 84.66 & 83.30 & 82.82 \\
CHAPs/THAPs & $0.32 \pm 0.12$ & $0.32 \pm 0.08$ & $0.41 \pm 0.13$ & $0.38 \pm 0.12$ & $0.44 \pm 0.11$ \\
BghiP/BeP & $2.40 \pm 1.62$ & $2.44 \pm 1.21$ & $4.02 \pm 2.34$ & $3.62 \pm 1.82$ & $3.40 \pm 2.36$ \\
IcdP/(IcdP + BghiP) & $0.39 \pm 0.17$ & $0.38 \pm 0.10$ & $0.29 \pm 0.12$ & $0.30 \pm 0.11$ & $0.35 \pm 0.13$ \\
Phe/(Phe + Ant) & $0.92 \pm 0.10$ & $0.87 \pm 0.09$ & $0.79 \pm 0.16$ & $0.84 \pm 0.11$ & $0.89 \pm 0.16$ \\
Flu/(Flu + Pyr) & $0.47 \pm 0.09$ & $0.46 \pm 0.08$ & $0.35 \pm 0.14$ & $0.40 \pm 0.08$ & $0.39 \pm 0.10$ \\
BaP/(BaP + BeP) & $0.26 \pm 0.05$ & $0.30 \pm 0.04$ & $0.27 \pm 0.10$ & $0.27 \pm 0.05$ & $0.32 \pm 0.10$ \\
BaPE (ng m $\left.{ }^{-3}\right)$ & $0.21 \pm 0.07$ & $0.23 \pm 0.10$ & $0.23 \pm 0.12$ & $0.22 \pm 0.11$ & $0.51 \pm 0.28$ \\
BaPE\% & 6.23 & 7.29 & 6.22 & 6.58 & 4.28 \\
Pri/Phy & $1.24 \pm 0.26$ & $1.42 \pm 0.81$ & $1.19 \pm 1.32$ & $1.29 \pm 0.39$ & $1.05 \pm 0.31$ \\
C29 $\alpha \beta / C 30 \alpha \beta$ & $1.19 \pm 0.25$ & $1.33 \pm 0.28$ & $1.34 \pm 0.44$ & $1.53 \pm 0.27$ & $1.61 \pm 0.26$ \\
OC/EC & 2.90 & 2.73 & 2.19 & 2.49 & 2.13 \\
\hline
\end{tabular}




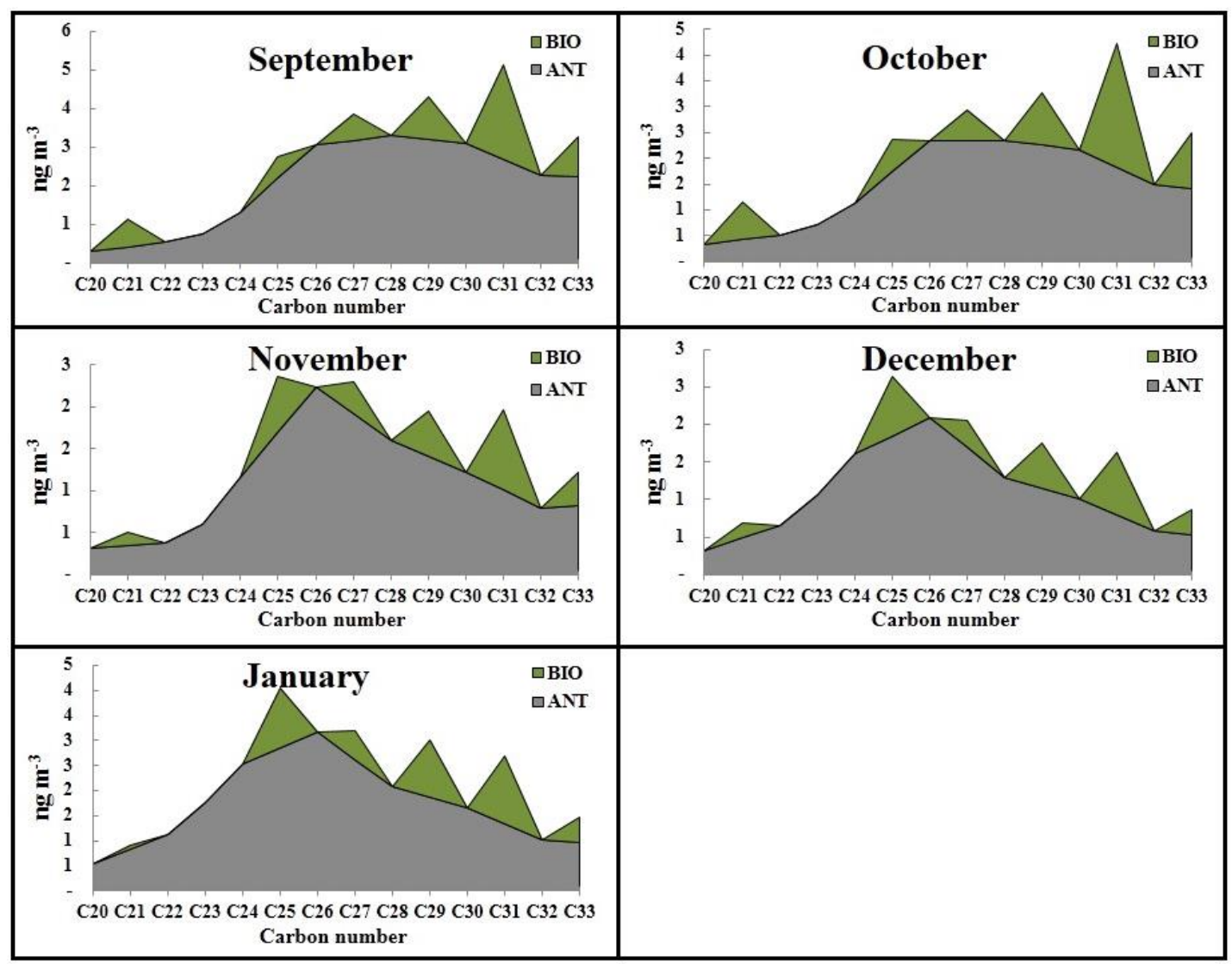

Fig. 12. Biogenic and anthropogenic contributions of $n$-alkanes in $\mathrm{PM}_{10}\left(\mathrm{ng} \mathrm{m}^{-3}\right)$ recorded over five months.

fuels during the five months. The $[\mathrm{IcdP} /(\mathrm{IcdP}+\mathrm{BghiP})]$ ratio reflects the importance of gasoline exhaust emissions, diesel particulates, and coal soot in the coastal region of Bou Ismail.

The $[\mathrm{Flu} /(\mathrm{Flu}+\mathrm{Pyr})]$ ratio value obtained in this study ranged from 0.35 to 0.47 during the five months. This value was similar to those previously documented for automobile emissions, particularly catalyst-equipped automobiles (del Rosario Sienra et al., 2005; Quiterio et al., 2007).

$\mathrm{The}[\mathrm{BaP} /(\mathrm{BaP}+\mathrm{BeP})]$ report was used to evaluate the photochemical reactivity of aerosols in the atmosphere. Indeed, $\mathrm{BaP}$ and $\mathrm{BeP}$ are emitted into the air with the same ratio $(1: 1)$ in several types of combustion. BeP is very stable, unlike $\mathrm{BaP}$, which is one of the most reactive pollutants in the particulate phase. There is a modification of the $[\mathrm{BaP}] /([\mathrm{BaP}]$ $+[\mathrm{BeP}])$ report away from the emission source. Therefore, $\mathrm{BaP}$ is prone to sunlight-induced decomposition as well as oxidants. Consequently, this ratio can be taken as an indicator of the aging of particles suspended in the air. The values of $[\mathrm{BaP}] /([\mathrm{BaP}]+[\mathrm{BeP}])(\sim 0.5)$ indicate that the aerosol is fresh, and if this ratio is even lower $(\sim 0)$, it shows that the air mass is rather old (Assami et al., 2018). In our samples, the ratios lied in the range $0.12-0.54$ (average 0.31 ) with the highest values obtained in January.

The $[\mathrm{BaP} /(\mathrm{BaP}+\mathrm{BeP})]$ ratio values obtained in this work suggest that the composition of the particles was amended somewhere by the reactivity of the atmosphere throughout the whole period, except in January when the aerosols were freshly emitted. This finding was in agreement with meteorological data of very high temperatures during the first months of sampling which accentuate the photochemical reaction. While for the last months of sampling, the temperature has dropped considerably which coincides with the difference in the results.

Overall, PAH diagnostic ratios indicate that both vehicular gasoline and diesel exhaust, particularly catalystequipped, were the major sources of organic aerosols in the Bou Ismaill coastal region.

\section{Risk Assessment and Toxicity of Aerosols}

Benzo[a]pyrene-equivalent carcinogenic power (BaPE) is an indicator for assessing the carcinogenic potential of aerosols, taking into account the most toxic PAHs. Many PAHs display toxic properties (IARC, 1987; U.S. EPA, 1993), and six of them (including BaA, BaP, PBF, Chr, DBahA, and IcdP) have been classified by U.S. EPA (1993) as possible carcinogens for humans. Due to its special potency (U.S. EPA, 1984; Collins et al., 1998), BaP was chosen by the World Health Organization (WHO) as an indicator of PAH-associated carcinogenicity. Nevertheless, a more complete indexing (regarding benzo[a]pyrene-equivalent carcinogenic power, BaPE) of particulates can be obtained by applying equivalency factors to all toxic PAHs and multiplying them by the respective concentrations in the air. Thus, the expression of BaPE proposed by the national committee of toxicology in Italy (1991) (Cecinato, 1997) has been improved by Khedidji et al. (2017). 

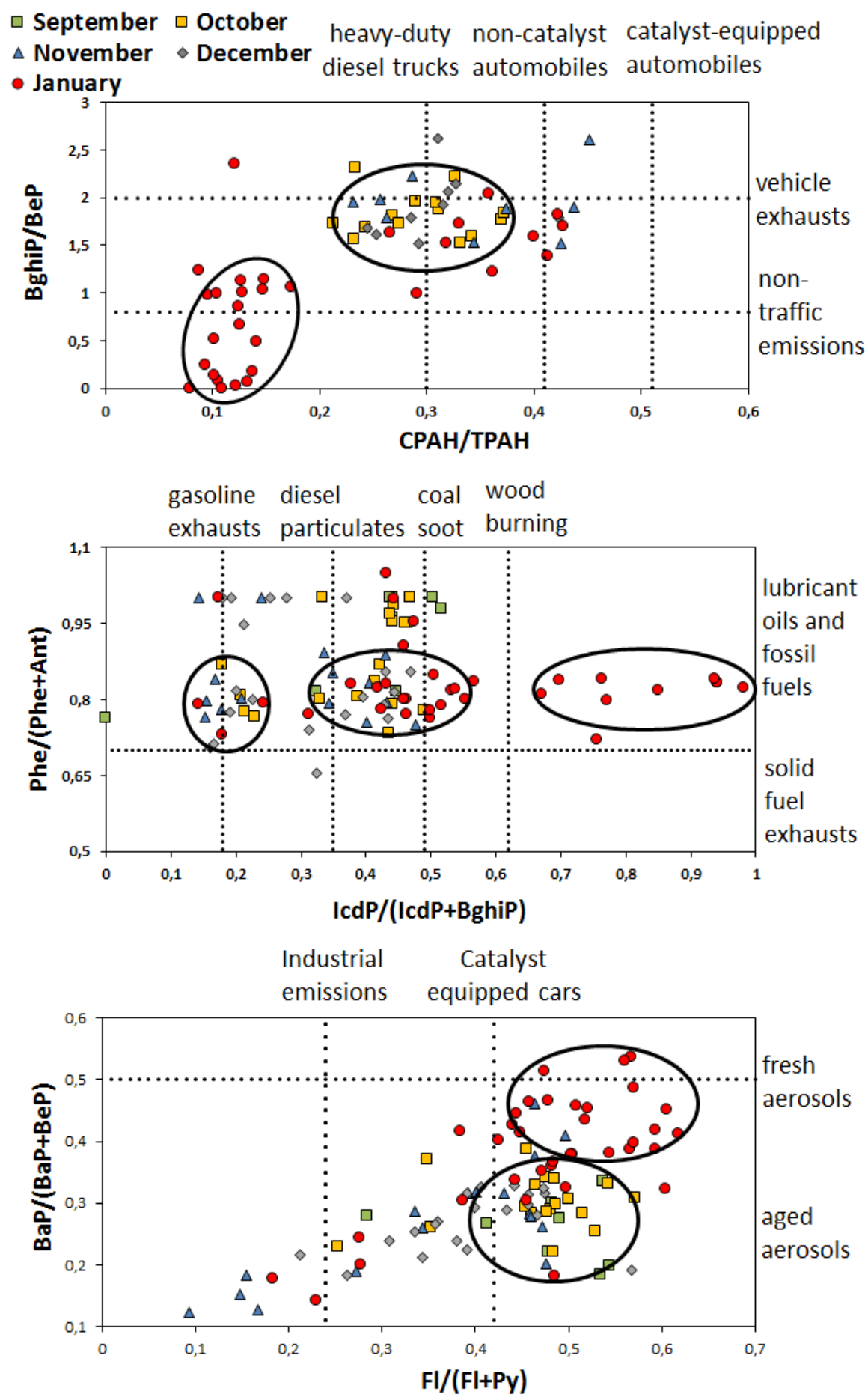

Fig. 13. Graphic illustration of the diagnostic ratios of the sources of PAH emissions.

Relative carcinogenicity was set at 1 , because uniformity has not yet been established. Hence:

$\mathrm{BaPE}=0.06 \times \mathrm{BaA}+0.07 \times \sum \mathrm{BFs}+\mathrm{BaP}+0.08 \times \mathrm{IcdP}+$ $0.6 \times$ DBahA

The BaPE values of the five months are reported in Table 5; the $\mathrm{BaPE}$ ratios ranged from 0.21 to $0.51 \mathrm{ng} \mathrm{m}^{-3}$, with the percentages of carcinogenic PAHs at $4.28 \%$ in January up to
$7.29 \%$ in October. The daily BaPE values exceeded the maximum permissible risk level of $1 \mathrm{ng} \mathrm{m}^{-3}$ set by the World Health Organization on one day: January $10^{\text {th }}$, which reveals that the health risk is minimal in the region. Overall, these values are higher than those obtained elsewhere in Algeria, such as in Boumerdes (0.03-0.18 $\left.\mathrm{ng} \mathrm{m}^{-3}\right)$, Rouiba-Réghaia $\left(0.08-0.49 \mathrm{ng} \mathrm{m}^{-3}\right)$, and the forest atmosphere of Chréa (0.005-0.034 $\mathrm{ng} \mathrm{m}^{-3}$ ) (Ladji et al., 2009b). 


\section{CONCLUSIONS}

A large dataset of constituents' concentrations in marine aerosol particles over the southern Mediterranean Sea was obtained between September 2011 and January 2012. It gave insights into the dominating sources of ambient $\mathrm{PM}_{10}$, which include marine and traffic emissions and the incomplete combustion of biomass. The concentrations of different species reached their maximum when the sampled air masses originated in southern Europe, as well as during the cold period.

Aerosol particles were rich in sulfate, nitrate, and ammonium, accounting for $65 \%$ of the total ions measured throughout the investigation. The contribution of dust was put in evidence by the crustal metals profile, including (Ba, $\mathrm{Ti}, \mathrm{Al}$, and $\mathrm{Fe}$ ), which contributed approximately $70 \%$ of the total concentrations of metal elements.

A Spearman rank correlation analysis between selected ions such as potassium, sulfate, ammonium, and oxalate demonstrates the strong influence of marine sources, secondary aerosol formation, and biomass burning.

The daily variations of concentrations in OC/EC were very similar throughout the entire study and within the range of a few $\mu \mathrm{g} \mathrm{m}^{-3}$. The assessment values of OCpri/OCsec show that carbonaceous materials are related to the secondary formation of precursors emitted during biomass burning.

The diagnostic ratios of speciated PAHs, the carbon preference indexes (CPI) of n-alkanes, and the OC/EC ratios showed that the emission of these pollutants was mainly due to petroleum combustion residues including vehicular emissions, while the plant waxes as biogenic source contributed relatively little. Additionally, the marked concentrations of pristane, phytane, and several hopane compounds were indicative of the high contribution of automobile exhaust emissions.

\section{ACKNOWLEDGMENTS}

This work was conducted as part of the National Exceptional Program (PNE) which was supported and financed by the Ministry of Higher Education and Scientific Research of Algeria. N012/PNE/ENS./ALLEMAGNE/2015-2016.

\section{SUPPLEMENTARY MATERIAL}

Supplementary data associated with this article can be found in the online version at https://doi.org/10.4209/aaqr.2 019.09.0458

\section{REFERENCES}

Assami, K., Ladji, R., Moussaoui, Y., Yassaa, N. and Meklati, B.Y. (2018). Influence of car body repair activities on particulate matter pollution in a suburban area (Bouzaréah City, Algiers). Int. J. Environ. Sci. Technol. 15: 10191028. https://doi.org/10.1007/s13762-017-1463-3

Balducci, C., Ladji, R., Muto, V., Romagnoli, P., Yassaa, N. and Cecinato, A. (2014). Biogenic and anthropogenic organic components of Saharan sands. Chemosphere 107: 129-
135. https://doi.org/10.1016/j.chemosphere.2014.02.069

Bauer, H., Claeys, M., Vermeylen, R., Schueller, E., Weinke, G., Berger, A. and Puxbaum, H. (2008). Arabitol and mannitol as tracers for the quantification of airborne fungal spores. Atmos. Environ. 42: 588-593. https://doi.org/10.1016/j.atmosenv.2007.10.013

Benchrif, A., Guinot, B., Bounakhla, M., Cachier, H., Damnati, B. and Baghdad, B. (2018). Aerosols in Northern Morocco: Input pathways and their chemical fingerprint. Atmos. Environ. 174: 140-147. https://doi.org/10.1016/j.a tmosenv.2017.11.047

Birch, M.E. and Cary, R.A. (1996). Elemental carbon-based method for monitoring occupational exposures to particulate diesel exhaust. Aerosol Sci. Technol. 25: 221241. https://doi.org/10.1080/02786829608965393

Birmili, W., Allen, A.G., Bary, F. and Harrison, R.M. (2006). Trace metal concentrations and water solubility in size-fractionated atmospheric particles and influence of road traffic. Environ. Sci. Technol. 40: 1144-1153. https://doi.org/10.1021/es0486925

Borgese, L., Salmistraro, M., Gianoncelli, A., Zacco, A., Lucchini, R., Zimmerman, N., Pisani, L., Siviero, G., Depero, L.E. and Bontempi, E. (2012). Airborne particulate matter (PM) filter analysis and modeling by total reflection X-ray fluorescence (TXRF) and X-ray standing wave (XSW). Talanta 89: 99-104. https://doi.org/10.101 6/j.talanta.2011.11.073

Bressi, M., Sciare, J., Ghersi, V., Bonnaire, N., Nicolas, J.B., Petit, J.E., Moukhtar, S., Rosso, A., Mihalopoulos, N. and Féron, A. (2013). A one-year comprehensive chemical characterisation of fine aerosol $\left(\mathrm{PM}_{2.5}\right)$ at urban, suburban and rural background sites in the region of Paris (France). Atmos. Chem. Phys. 13: 7825-7844. https://doi.org/10.51 94/acp-13-7825-2013

Cecinato, A., Guerriero, E., Balducci, C. and Muto, V. (2014). Use of the PAH fingerprints for identifying pollution sources. Urban Clim. 10: 630-643. https://doi.org/10.101 6/j.uclim.2014.04.004

Cheng, M.C., You, C.F., Cao, J. and Jin, Z. (2012). Spatial and seasonal variability of water-soluble ions in $\mathrm{PM}_{2.5}$ aerosols in 14 major cities in China. Atmos. Environ. 60: 182-92. https://doi.org/10.1016/j.atmosenv.2012.06.037

Collins, J.F., Brown, J.P., Alexeeff, G.V. and Salmon, A.G. (1998). Potency equivalency factors for some polycyclic aromatic hydrocarbons and polycyclic aromatic hydrocarbon derivatives. Regul. Toxicol. Pharm. 28: 4554. https://doi.org/10.1006/rtph.1998.1235

Contini, D., Belosi, F., Gambaro, A., Cesari, D., Stortini, A.M. and Bove, M.C. (2012). Comparison of $\mathrm{PM}_{10}$ concentrations and metal content in three different sites of the Venice Lagoon: An analysis of possible aerosol sources. J. Environ. Sci. 24: 1954-1965. https://doi.org/1 0.1016/S1001-0742(11)61027-9

Custódio, D., Cerqueira. M., Alves, C., Nunes, T., Pio, C., Esteves, V., Frosini, D., Lucarelli, F. and Querol, X. (2016). A one-year record of carbonaceous components and major ions in aerosols from an urban kerbside location in Oporto, Portugal. Sci. Total Environ. 562: 822-833. https://doi.org/10.1016/j.scitotenv.2016.04.012 
del Rosario Sienra, M., Rosazza, N.G. and Préndez, M. (2005). Polycyclic aromatic hydrocarbons and their molecular diagnostic ratios in urban atmospheric respirable particulate matter. Atmos. Res. 75: 267-281. https://doi.org/10.1016/j.atmosres.2005.01.003

Deshmukh, D.K., Deb, M.K., Suzuki, Y. and Kouvarakis, G.N. (2013). Water-soluble ionic composition of $\mathrm{PM}_{2.5-10}$ and $\mathrm{PM}_{2.5}$ aerosols in the lower troposphere of an industrial city Raipur, the eastern central India. Air Qual. Atmos. Health 6: 95-110. https://doi.org/10.1007/s11869011-0149-0

Di Vaio, P., Cocozziello, B., Corvino, A., Fiorino, F., Frecentese, F., Magli, E., Onorati, G., Saccone, I., Santagada, V., Settimo, G., Severino, B. and Perissutti, E. (2016) Level, potential sources of Polycyclic Aromatic Hydrocarbons (PAHs) in particulate matter $\left(\mathrm{PM}_{10}\right)$ in Naples. Atmos. Environ. 129: 186-196. https://doi.org/10. 1016/j.atmosenv.2016.01.020

Directive 2008/50/EC of the European Parliament and of the Council of 21 May 2008 on ambient air quality and cleaner air for Europe 152: 1-44.

Draxler, R.R. and Rolph, G.D. (2003). HYSPLIT (HYbrid Single-Particle Lagrangian Integrated Trajectory) Model. NOAA Air Resources Laboratory, http://www.arl.noaa.g ov/ready/hysplit4.html

Ebert, M., Weinbruch, S., Hoffmann, P. and Ortner, H.M. (2000). Chemical characterization of North Sea aerosol particles. J. Aerosol Sci. 31:613-632. https://doi.org/10.1 016/S0021-8502(99)00549-2

El Haddad, I., Marchand, N., Dron, J., Temime-Roussel, B., Quivet, E., Wortham, H., Jaffrezo, J.L., Baduel, C., Voisin, D., Besombes, J.L. and Gille, G. (2009). Comprehensive primary particulate organic characterization of vehicular exhaust emissions in France. Atmos. Environ. 43: 6190 6198. https://doi.org/10.1016/j.atmosenv.2009.09.001

Fomba, K.W., Müller, K., van Pinxteren, D. and Herrmann, H. (2013). Aerosol size-resolved trace metal composition in remote northern tropical Atlantic marine environment: case study Cape Verde islands. Atmos. Chem. Phys. 13: 4801-4814. https://doi.org/10.5194/acp-13-4801-2013

Fomba, K.W., Pinxteren, D. van Müller, K., Spindler, G. and Herrmann, H. (2018). Assessment of trace metal levels in size-resolved particulate matter in the area of Leipzig. Atmos. Environ. 176: 60-70. https://doi.org/10.1016/j.at mosenv.2017.12.024

Fu, P.Q., Kawamura, K., Pavuluri, C.M., Swaminathan, T. and Chen, J. (2010). Molecular characterization of urban organic aerosol in tropical India: Contributions of primary emissions and secondary photooxidation. Atmos. Chem. Phys. 10: 2663-2689. https://doi.org/10.5194/acp-102663-2010

Fu, P., Kawamura, K., Kobayashi, M. and Simoneit, B.R.T. (2012). Seasonal variations of sugars in atmospheric particulate matter from Gosan, Jeju Island: Significant contributions of airborne pollen and Asian dust in spring. Atmos. Environ. 55: 234-239. https://doi.org/10.1016/j.at mosenv.2012.02.061

Fu, P., Zhuang, G., Sun, Y., Wang, Q., Chen, J., Ren, L., Yang, F., Wang, Z., Pan, X., Li, X. and Kawamura, K.
(2016). Molecular markers of biomass burning, fungal spores and biogenic SOA in the Taklimakan desert aerosols. Atmos. Environ. 130: 64-73. https://doi.org/10.1 016/j.atmosenv.2015.10.087

Galindo, N., Yubero, E., Nicolás, J.F., Crespo, J., Varea, M. and Gil-Moltó, J. (2017). Regional and long-range transport of aerosols at Mt. Aitana, Southeastern Spain. Sci. Total Environ. 584-585: 723-730. https://doi.org/10.1016/j.sci totenv.2017.01.108

Han, Y.M., Lee, S.C., Cao, J.J., Ho, K.F. and An, Z.S. (2009). Spatial distribution and seasonal variation of charEC and soot-EC in the atmosphere over China. Atmos. Environ. 43: 6066-6073. https://doi.org/10.1016/j.atmos env.2009.08.018

Hays, M.D., Fine, P.M., Geron, C.D., Kleeman, M.J. and Gullett, B.K. (2005). Open burning of agricultural biomass: Physical and chemical properties of particlephase emissions. Atmos. Environ. 39: 6747-6764. https://doi.org/10.1016/j.atmosenv.2005.07.072

He, J., Zielinska, B. and Balasubramanian, R. (2010). Composition of semi-volatile organic compounds in the urban atmosphere of Singapore: Influence of biomass burning. Atmos. Chem. Phys. 10: 11401-11413. https://doi.org/10.5194/acp-10-11401-2010

Hu, H., Tian, M., Zhang, L., Yang, F., Peng, C., Chen, Y., Shi, G., Yao, X., Jiang, C. and Wang, J. (2019). Sources and gas-particle partitioning of atmospheric parent, oxygenated, and nitrated polycyclic aromatic hydrocarbons in a humid city in southwest China. Atmos. Environ. 206: 1-10. https://doi.org/10.1016/j.atmosenv.2019.02.041

Iinuma, Y., Engling, G., Puxbaum, H. and Herrmann, H. (2009). A highly resolved anion-exchange chromatographic method for determination of saccharidic tracers for biomass combustion and primary bio-particles in atmospheric aerosol. Atmos. Environ. 43: 1367-1371. https://doi.org/10.1016/j.atmosenv.2008.11.020

International Agency for Research on Cancer (IARC) (1987). IARC monographs on the evaluation of carcinogenic risks to humans, Supplement 7, Overall Evaluations of Carcinogenicity: An Updating of IARC Monographs Volumes 1 to 42, Lyon.

International Agency for Research on Cancer (IARC) (2005). IARC Handbooks of Cancer Prevention Volume 10: Cervix Cancer Screening. International Agency for Research on Cancer, IARCpress.

Kavouras, I.G. (2002). Particle size distribution of organic primary and secondary aerosol constituents in urban, background marine, and forest atmosphere. J. Geophys. Res. 107. https://doi.org/10.1029/2000JD000278

Kawamura, K. and Sakaguchi, F. (1999). Molecular distributions of water soluble dicarboxylic acids in marine aerosols over the Pacific Ocean including tropics. $J$. Geophys. Res. 104: 3501-3509. https://doi.org/10.1029/1 998JD100041

Kawamura, K. and Bikkina, S. (2016). A review of dicarboxylic acids and related compounds in atmospheric aerosols: Molecular distributions, sources and transformation. Atmos. Res. 170: 140-160. https://doi.org/ 10.1016/j.atmosres.2015.11.018 
Kelly, F.J. and Fussell, J.C. (2012). Size, source and chemical composition as determinants of toxicity attributable to ambient particulate matter. Atmos. Environ. 60: 504-526. https://doi.org/10.1016/j.atmosenv.2012.06.039

Khedidji, S., Ladji, R. and Yassaa, N. (2013). A wintertime study of polycyclic aromatic hydrocarbons (PAHs) in indoor and outdoor air in a big student residence in Algiers, Algeria. Environ. Sci. Pollut. Res. 20: 49064919. https://doi.org/10.1007/s11356-012-1430-y

Khedidji, S., Balducci, C., Ladji, R., Cecinato, A., Perilli, M. and Yassaa, N. (2017). Chemical composition of particulate organic matter at industrial, university and forest areas located in Bouira province, Algeria. Atmos. Pollut. Res. 8: 474-482. https://doi.org/10.1016/j.apr.2016.12.005

Kumar, A., Sarin, M.M and Sudheer, A.K. (2008). Mineral and anthropogenic aerosols in Arabian Sea-atmospheric boundary layer: Sources and spatial variability. Atmos. Environ. 42: 5169-5181. https://doi.org/10.1016/j.atmos env.2008.03.004

Ladji, R., Yassaa, N., Balducci, C., Cecinato, A. and Meklati, B.Y. (2009a). Annual variation of particulate organic compounds in $\mathrm{PM}_{10}$ in the urban atmosphere of Algiers. Atmos. Res. 92: 258-269. https://doi.org/10.1016/j.atmos res.2008.12.002

Ladji, R., Yassaa, N., Balducci, C., Cecinato, A. and Meklati, B.Y. (2009b) Distribution of the solvent-extractable organic compounds in fine $\left(\mathrm{PM}_{1}\right)$ and coarse $\left(\mathrm{PM}_{1-10}\right)$ particles in urban, industrial and forest atmospheres of Northern Algeria. Sci. Total Environ. 408: 415-424. https://doi.org/10.1016/j.scitotenv.2009.09.033

Ladji, R., Yassaa, N., Balducci, C. and Cecinato, A. (2014). Particle size distribution of n-alkanes and polycyclic aromatic hydrocarbons (PAHS) in urban and industrial aerosol of Algiers, Algeria. Environ. Sci. Pollut. Res. 21: 1819-1832. https://doi.org/10.1007/s11356-013-2074-2

Legrand, M., Preunkert, S., Oliveira, T., Pio, C.A., Hammer, S., Gelencsér, A., Kasper-Giebl, A. and Laj, P. (2007). Origin of $\mathrm{C}_{2}-\mathrm{C}_{5}$ dicarboxylic acids in the European atmosphere inferred from year-round aerosol study conducted at a west-east transect. J. Geophys. Res. 112: D23S07. https://doi.org/10.1029/2006JD008019

Li, J., Peng, X., Zhou, H., Li, J., Chen, S., Wu, Z. and Yao, H. (2012). Characteristics and source of polycyclic aromatic hydrocarbons in the surface hydrothermal sediments from two hydrothermal fields of the Central Indian and Mid-Atlantic Ridges. Geochem. J. 46: 31-43. https://doi.org/10.2343/geochemj.1.0150

Li, L., Yin, Y., Kong, S., Wen, B., Chen, K., Yuan, L. and Li, Q. (2014). Altitudinal effect to the size distribution of water soluble inorganic ions in PM at Huangshan, China. Atmos. Environ. 98: 242-252. https://doi.org/10.1016/j.a tmosenv.2014.08.077

Li, W., Peng, Y. and Bai, Z. (2010). Distributions and sources of n-alkanes in $\mathrm{PM}_{2.5}$ at urban, industrial and coastal sites in Tianjin, China. J. Environ. Sci. 22: 15511557. https://doi.org/10.1016/S1001-0742(09)60288-6

Li, X., Wang, L., Ji, D., Wen, T., Pan, Y., Sun, Y. and Wang, Y. (2013). Characterization of the size-segregated watersoluble inorganic ions in the Jing-Jin-Ji urban agglomeration: Spatial/temporal variability, size distribution and sources. Atmos. Environ. 77: 250-259. https://doi.org/10.1016/j.atmosenv.2013.03.042

Liang, C.S., Duan, F.K., He, K.B. and Ma, Y.L. (2016a). Review on recent progress in observations, source identifications and countermeasures of $\mathrm{PM}_{2.5}$. Environ. Int. 86: 150-170. https://doi.org/10.1016/j.envint.2015.10.016

Liang, L., Engling, G., Du, Z., Cheng, Y., Duan, F., Liu, X. and $\mathrm{He}, \mathrm{K}$. (2016b). Seasonal variations and source estimation of saccharides in atmospheric particulate matter in Beijing, China. Chemosphere 150: 365-377. https://doi.org/10.1016/j.chemosphere.2016.02.002

Lippmann, M. and Chen, L.C. (2009). Health effects of concentrated ambient air particulate matter (CAPs) and its components. Crit. Rev. Toxicol. 39: 865-913. https://doi.org/10.3109/10408440903300080

Meng, C.C., Wang, L.T., Zhang, F.F., Wei, Z., Ma, S.M., Ma, X. and Yang, J. (2016). Characteristics of concentrations and water-soluble inorganic ions in $\mathrm{PM}_{2.5}$ in Handan City, Hebei province, China. Atmos. Res. 171: 133-146. https://doi.org/10.1016/j.atmosres.2015.12.013

Morales, J.A., Pirela, D., Nava, M.G. de Borrego, B.S. de Velásquez, H. and Durán, J. (1998). Inorganic water soluble ions in atmospheric particles over Maracaibo Lake Basin in the western region of Venezuela. Atmos. Res. 46: 307-320. https://doi.org/10.1016/S0169-8095(97)00071-9

Müller, K., Lehmann, S., van Pinxteren, D., Gnauk, T., Niedermeier, N., Wiedensohler, A. and Herrmann, H. (2010). Particle characterization at the Cape Verde atmospheric observatory during the 2007 RHaMBLe intensive. Atmos. Chem. Phys. 10: 2709-2721. https://doi.org/10.5194/acp-10-2709-2010

National Institute for Occupational Safety and Health (NIOSH) (1998). NIOSH method 5040. In NIOSH manual of analytical methods (NMAM), 4th ed., 2nd supplement edited by Cassinelli, M.E., O'Connor, P.F., supplement to DHHS (NIOSH) publication, pp. 94-113.

Oliveira, R.L., Loyola, J., Minho, A.S., Quiterio, S.L., de Almeida Azevedo, D. and Arbilla, G. (2014). PM $_{2.5^{-}}$ bound polycyclic aromatic hydrocarbons in an area of Rio de Janeiro, Brazil impacted by emissions of light-duty vehicles fueled by ethanol-blended gasoline. Bull. Environ. Contam. Toxicol. 93: 781-786. https://doi.org/10.1007/s0 0128-014-1409-0

Oros, D.R. and Simoneit, B.R.T. (2000). Identification and emission rates of molecular tracers in coal smoke particulate matter. Fuel 79: 515-536. https://doi.org/10.1 016/S0016-2361(99)00153-2

Öztürk, F., Zararsız, A., Dutkiewicz, V.A., Husain, L., Hopke, P.K. and Tuncel, G. (2012). Temporal variations and sources of Eastern Mediterranean aerosols based on a 9-year observation. Atmos. Environ. 61: 463-475. https://doi.org/10.1016/j.atmosenv.2012.07.051

Pathak, R.K., Wang, T., Ho, K.F. and Lee, S.C. (2011). Characteristics of summertime $\mathrm{PM}_{2.5}$ organic and elemental carbon in four major Chinese cities: Implications of high acidity for water-soluble organic carbon (WSOC). Atmos. Environ. 45: 318-325. https://doi.org/10.1016/j.atmosen v.2010.10.021 
People's Democratic Republic of Algeria (2006) Executive Decree No 06-02 of 07 January 2006, page 3, defining value limits, alert thresholds and air quality objectives in case of atmospheric pollution in Algeria (in French) People's Democratic Republic of Algeria.

Perrone, M.G., Vratolis, S., Georgieva, E., Török, S., Šega, K., Veleva, B., Osán, J., Bešlić, I., Kertész, Z., Pernigotti, D., Eleftheriadis, K. and Belis, C.A. (2018). Sources and geographic origin of particulate matter in urban areas of the Danube macro-region: The cases of Zagreb (Croatia), Budapest (Hungary) and Sofia (Bulgaria). Sci. Total Environ. 619-620: 1515-1529. https://doi.org/10.1016/j. scitotenv.2017.11.092

Pey, J., Querol, X. and Alastuey, A. (2010). Discriminating the regional and urban contributions in the North-Western Mediterranean: PM levels and composition. Atmos. Environ. 44: 1587-1596. https://doi.org/10.1016/j.atmos env.2010.02.005

Pey, J., Pérez, N., Cortés, J., Alastuey, A. and Querol, X. (2013) Chemical fingerprint and impact of shipping emissions over a western Mediterranean metropolis: Primary and aged contributions. Sci. Total Environ. 463464: 497-507. https://doi.org/10.1016/j.scitotenv.2013.0 6.061

Pietrogrande, M.C., Perrone, M.R., Manarini, F., Romano, S., Udisti, R. and Becagli, S. (2018). $\mathrm{PM}_{10}$ oxidative potential at a Central Mediterranean Site: Association with chemical composition and meteorological parameters. Atmos. Environ. 188: 97-111. https://doi.org/10.1016/j.a tmosenv.2018.06.013

Pio, C.A., Alves, C.A. and Duarte, A.C. (2001). Identification, abundance and origin of atmospheric organic particulate matter in a Portuguese rural area. Atmos. Environ. 35: 13651375. https://doi.org/10.1016/S1352-2310(00)00391-5

Putaud, J.P., Raes, F., Van Dingenen, R., Brüggemann, E., Facchini, M.C., Decesari, S., Fuzzi, S., Gehrig, R., Hüglin, C., Laj, P., Lorbeer, G., Maenhaut, W., Mihalopoulos, N., Müller, K., Querol, X., Rodriguez, S., Schneider, J., Spindler, G., ten Brink, H., ... Wiedensohler, A. (2004). A European aerosol phenomenology 2: Chemical characteristics of particulate matter at kerbside, urban, rural and background sites in Europe. Atmos. Environ. 38: 25792595. https://doi.org/10.1016/j.atmosenv.2004.01.041

Quinn, P.K. (2004). Aerosol optical properties measured on board the Ronald $\mathrm{H}$. Brown during ACE-Asia as a function of aerosol chemical composition and source region. J. Geophys. Res. 109: D19S01. https://doi.org/10. 1029/2003JD004010

Quiterio, S.L., Arbilla, G., Bauerfeldt, G.F. and Moreira, J.C. (2007). Polycyclic aromatic hydrocarbons and their molecular diagnostic ratios in airborne particles $\left(\mathrm{PM}_{10}\right)$ collected in Rio de Janeiro, Brazil. Water Air Soil Pollut. 179: 79-92. https://doi.org/10.1007/s11270-006-9215-x

Rabhi, L., Lemou, A., Cecinato, A., Balducci, C., Cherifi, N., Ladji, R. and Yassaa, N. (2018). Polycyclic aromatic hydrocarbons, phthalates, parabens and other environmental contaminants in dust and suspended particulates of Algiers, Algeria. Environ. Sci. Pollut. Res. 25: 24253 24265. https://doi.org/10.1007/s11356-018-2496-y
Reche, C., Viana, M., Amato, F., Alastuey, A., Moreno, T., Hillamo, R., Teinilä, K., Saarnio, K., Seco, R., Peñuelas, J., Mohr, C., Prévôt, A.S.H. and Querol, X. (2012). Biomass burning contributions to urban aerosols in a coastal Mediterranean City. Sci. Total Environ. 427-428: 175-190. https://doi.org/10.1016/j.scitotenv.2012.04.012

Rinaldi, M., Decesari, S., Carbone, C., Finessi, E., Fuzzi, S., Ceburnis, D., O’Dowd, C.D., Sciare, J., Burrows, J.P., Vrekoussis, M., Ervens, B., Tsigaridis, K. and Facchini, M.C. (2011). Evidence of a natural marine source of oxalic acid and a possible link to glyoxal. J. Geophys. Res. 116: D16204. https://doi.org/10.1029/2011JD015659

Romagnoli, P., Balducci, C., Perilli, M., Perreca, E. and Cecinato, A. (2016). Particulate PAHs and n-alkanes in the air over Southern and Eastern Mediterranean Sea. Chemosphere 159: 516-525. https://doi.org/10.1016/j.ch emosphere.2016.06.024

Russell, M. and Allen, D.T. (2004). Seasonal and spatial trends in primary and secondary organic carbon concentrations in southeast Texas. Atmos. Environ. 38: 3225-3239. https://doi.org/10.1016/j.atmosenv.2004.03. 013

Sánchez de la Campa, A.M., de la Rosa, J., GonzálezCastanedo, Y., Fernández-Camacho, R., Alastuey, A., Querol, X., Stein, A.F., Ramos, J.L., Rodríguez, S., Orellana, I.G. and Nava, S. (2011). Levels and chemical composition of $\mathrm{PM}$ in a city near a large $\mathrm{Cu}$-smelter in Spain. $J$. Environ. Monit. 13: 1276. https://doi.org/10.1039/c0em0 0708k

Satsangi, P.G., Yadav, S., Pipal, A.S. and Kumbhar, N. (2014). Characteristics of trace metals in fine $\left(\mathrm{PM}_{2.5}\right)$ and inhalable $\left(\mathrm{PM}_{10}\right)$ particles and its health risk assessment along with in-silico approach in indoor environment of India. Atmos. Environ. 92: 384-393. https://doi.org/10.10 16/j.atmosenv.2014.04.047

Scaramboni, C., Urban, R.C., Lima-Souza, M., Nogueira, R.F.P., Cardoso, A.A., Allen, A.G. and Campos, M.L.A.M. (2015). Total sugars in atmospheric aerosols: An alternative tracer for biomass burning. Atmos. Environ. 100: 185-192. https://doi.org/10.1016/j.atmosenv.2014.11.003

Schauer, J.J., Kleeman, M.J., Cass, G.R. and Simoneit, B.R.T. (2002). Measurement of emissions from air pollution sources. 4. $\mathrm{C}_{1}-\mathrm{C}_{27}$ organic compounds from cooking with seed oils. Environ. Sci. Technol. 36: 567575. https://doi.org/10.1021/es002053m

Scheinhardt, S., Spindler, G., Leise, S., Müller, K., Iinuma, Y., Zimmermann, F., Matschullat, J. and Herrmann, H. (2013). Comprehensive chemical characterisation of sizesegregated $\mathrm{PM}_{10}$ in Dresden and estimation of changes due to global warming. Atmos. Environ. 75: 365-373. https://doi.org/10.1016/j.atmosenv.2013.04.059

Seinfeld, J.H. and Pandis, S.N. (1998). Atmospheric Chemistry and Physics: From air pollution to climate change. John Wiley \& Sons.

Simoneit, B.R.T. (1984). Organic Matter of the Troposphere III. Characterization and sources of petroleum and pyrogenic residues in aerosols over the western united states. Atmos. Environ. 1967 18: 51-67. https://doi.org/10. 1016/0004-6981(84)90228-2 
Simoneit, B.R.T., Sheng, G., Chen, X., Fu, J., Zhang, J. and $\mathrm{Xu}$, Y. (1991). Molecular marker study of extractable organic matter in aerosols from urban areas of China. Atmos. Environ. 25: 2111-2129. https://doi.org/10.1016/ 0960-1686(91)90088-O

Spindler, G., Gnauk, T., Grüner, A., Iinuma, Y., Müller, K., Scheinhardt, S. and Herrmann, H. (2012). Size-segregated characterization of $\mathrm{PM}_{10}$ at the EMEP site Melpitz (Germany) using a five-stage impactor: A six year study. J. Atmos. Chem. 69: 127-157. https://doi.org/10.1007/s1 0874-012-9233-6

Srogi, K. (2007). Monitoring of environmental exposure to polycyclic aromatic hydrocarbons: A review. Environ. Chem. Lett. 5: 169-195. https://doi.org/10.1007/s10311007-0095-0

Sun, Y., Zhuang, G., Wang, Y., Han, L., Guo, J., Dan, M., Zhang, W., Wang, Z. and Hao, Z. (2004). The air-borne particulate pollution in Beijing - concentration, composition, distribution and sources. Atmos. Environ. 38: 5991-6004. https://doi.org/10.1016/j.atmosenv.2004.07.009

Tang, X.B., Huang, C., Lou, S.R., Qiao, L.P., Wang, H.L., Zhou, M., Chen, M., Chen, C.H., Wang, Q., Li, G.L., Li, L., Huang, H.Y. and Zhang, G.F. (2014). Emission factors and PM chemical composition study of biomass burning in the Yangtze River Delta region. Huan Jing Ke Xue Huanjing Kexue 35: 1623-1632.

United States Environmental Protection Agency (U.S. EPA) (1993). Provisional guidance for quantitative risk assessment of polycyclic aromatic hydrocarbons, EPA/600/R93/089. United States Environmental Protection Agency. van Pinxteren, D., Neusüß, C. and Herrmann, H. (2014). On the abundance and source contributions of dicarboxylic acids in size-resolved aerosol particles at continental sites in central Europe. Atmos. Chem. Phys. 14: 3913-3928. https://doi.org/10.5194/acp-14-3913-2014

van Pinxteren, M., Fiedler, B., van Pinxteren, D., Iinuma, Y., Körtzinger, A. and Herrmann, H. (2015). Chemical characterization of sub-micrometer aerosol particles in the tropical Atlantic Ocean: Marine and biomass burning influences. J. Atmos. Chem. 72: 105-125. https://doi.org/ 10.1007/s10874-015-9307-3

Viana, M., Pandolfi, M., Minguillón, M.C., Querol, X., Alastuey, A., Monfort, E. and Celades, I. (2008). Intercomparison of receptor models for PM source apportionment: Case study in an industrial area. Atmos. Environ. 42: 3820-3832. https://doi.org/10.1016/j.atmose nv.2007.12.056

Vicente, A., Alves, C., Monteiro, C., Nunes, T., Mirante, F., Cerqueira, M., Calvo, A. and Pio, C. (2012). Organic speciation of aerosols from wildfires in central Portugal during summer 2009. Atmos. Environ. 57: 186-196. https://doi.org/10.1016/j.atmosenv.2012.04.030

Waked, A., Afif, C., Formenti, P., Chevaillier, S., El-Haddad, I., Doussin, J.F., Borbon, A. and Seigneur, C. (2014). Characterization of organic tracer compounds in $\mathrm{PM}_{2.5}$ at a semi-urban site in Beirut, Lebanon. Atmos. Res. 143: 85-94. https://doi.org/10.1016/j.atmosres.2014.02.006

Wang, G., Kawamura, K., Xie, M., Hu, S., Gao, S., Cao, J., An, Z. and Wang, Z. (2009). Size-distributions of n- alkanes, PAHs and hopanes and their sources in the urban, mountain and marine atmospheres over East Asia. Atmos. Chem. Phys. 9: 8869-8882. https://doi.org/10.5194/acp9-8869-2009

Wang, Y., Zhuang, G., Tang, A., Yuan, H., Sun, Y., Chen, S. and Zheng, A. (2005). The ion chemistry and the source of $\mathrm{PM}_{2.5}$ aerosol in Beijing. Atmos. Environ. 39: 37713784. https://doi.org/10.1016/j.atmosenv.2005.03.013

Wang, Y., Zhuang, G., Zhang, X., Huang, K., Xu, C., Tang, A., Chen, J. and An, Z. (2006). The ion chemistry, seasonal cycle, and sources of $\mathrm{PM}_{2.5}$ and TSP aerosol in Shanghai. Atmos. Environ. 40: 2935-2952. https://doi.org/10.1016/j. atmosenv.2005.12.051

World Health Organization (WHO) (2006). Air quality guidelines: Global update 2005: Particulate matter, ozone, nitrogen dioxide, and sulfur dioxide. World Health Organization, Geneva.

Xiang, P., Zhou, X., Duan, J., Tan, J., He, K., Yuan, C., Ma, Y. and Zhang, Y. (2017). Chemical characteristics of water-soluble organic compounds (WSOC) in $\mathrm{PM}_{2.5}$ in Beijing, China: 2011-2012. Atmos. Res. 183: 104-112. https://doi.org/10.1016/j.atmosres.2016.08.020

Yassaa, N. and Cecinato, A. (2005). Composition of torched crude oil organic particulate emitted by refinery and its similarity to atmospheric aerosol in the surrounding area. Chemosphere 60: 1660-1666. https://doi.org/10.1016/j.c hemosphere.2005.02.041

Yassaa, N., Youcef, B.M., Cecinato, A. and Marino, F. (2001a). Chemical characteristics of organic aerosol in Bab-Ezzouar (Algiers). Contribution of bituminous product manufacture. Chemosphere 45: 315-322. https://doi.org/ 10.1016/S0045-6535(00)00566-X

Yassaa, N., Youcef, B.M., Cecinato, A. and Marino, F. (2001b). Particulate n-alkanes, n-alkanoic acids and polycyclic aromatic hydrocarbons in the atmosphere of Algiers City Area. Atmos. Environ. 35: 1843-1851. https://doi.org/10.1016/S1352-2310(00)00514-8

Yin, L., Niu, Z., Chen, X., Chen, J., Zhang, F. and Xu, L. (2014). Characteristics of water-soluble inorganic ions in $\mathrm{PM}_{2.5}$ and $\mathrm{PM}_{2.5-10}$ in the coastal urban agglomeration along the Western Taiwan Strait Region, China. Environ. Sci. Pollut. Res. 21: 5141-5156. https://doi.org/10.1007/ s11356-013-2134-7

Yue, Z.W. and Fraser, M.P. (2004). Characterization of nonpolar organic fine particulate matter in houston, texas special issue of aerosol science and technology on findings from the fine particulate matter supersites program. Aerosol Sci. Technol. 38:60-67. https://doi.org/ 10.1080/02786820390229444

Zhao, X.J., Zhao, P.S., Xu, J., Meng, W., Pu, W.W., Dong, F., He, D. and Shi, Q.F. (2013). Analysis of a winter regional haze event and its formation mechanism in the North China Plain. Atmos. Chem. Phys. 13: 5685-5696. https://doi.org/10.5194/acp-13-5685-2013

Zhao, Y. and Gao, Y. (2008). Mass size distributions of water-soluble inorganic and organic ions in size-segregated aerosols over metropolitan Newark in the US east coast. Atmos. Environ. 42: 4063-4078. https://doi.org/10.1016/ j.atmosenv.2008.01.032 
Zhou, J., Xing, Z., Deng, J. and Du, K. (2016). Characterizing and sourcing ambient $\mathrm{PM}_{2.5}$ over key emission regions in China I: Water-soluble ions and carbonaceous fractions. Atmos. Environ. 135: 20-30. https://doi.org/10.1016/j.atm osenv.2016.03.054

Zhu, C.S., Cao, J.J., Tsai, C.J., Shen, Z.X., Han, Y.M., Liu, S.X. and Zhao, Z.Z. (2014). Comparison and implications of $\mathrm{PM}_{2.5}$ carbon fractions in different environments. Sci. Total Environ. 466-467: 203-209. https://doi.org/10.101 6/j.scitotenv.2013.07.029

Zhu, J., Hsu, C.Y., Chou, W.C., Chen, M.J., Chen, J.L.,
Yang, T.T., Wu, Y.S. and Chen, Y.C. (2019). $\mathrm{PM}_{2.5^{-}}$and $\mathrm{PM}_{10}$-bound polycyclic aromatic hydrocarbons (PAHs) in the residential area near coal-fired power and steelmaking plants of Taichung City, Taiwan: In vitro-based health risk and source identification. Sci. Total Environ. 670: 439-447. https://doi.org/10.1016/j.scitotenv.2019.03.198

Received for December 24, 2019

Revised, July 3, 2020

Accepted, July 26, 2020 